\section{D) Check for updates}

Cite this: Nat. Prod. Rep., 2019, 36, 289

\title{
2-Formylpyrrole natural products: origin, structural diversity, bioactivity and synthesis
}

\author{
James M. Wood, ${ }^{a}$ Daniel P. Furkert (iD) *a and Margaret A. Brimble (D)*ab
}

\begin{abstract}
Covering: up to April 2018
2-Formylpyrroles are ubiquitous in nature, arising from the non-enzymatic Maillard reactions of amines and sugars. Often confused for secondary metabolites, these Maillard products display interesting biological activities including hepatoprotective, immunostimulatory, antiproliferative and antioxidant effects. This review presents all 2 -formylpyrrole natural products reported to date and identifies structural sub-classes for their categorisation. The origin, biological activity and chemical syntheses of these natural products are discussed herein.
\end{abstract}

rsc.li/npr

enzymatic biosynthesis has been proposed for these

1. Introduction

2. Non-enzymatic origin

3. Structural diversity and bioactivity

3.1. 2-Formylpyrroles derived from amino acids

3.2. 2-Formylpyrroles derived from biogenic amines

3.3. $N$-Unsubstituted 2-formylpyrroles derived from amino sugars

3.4. Pyrrolomorpholine spiroketals derived from amino sugars

4. Synthesis

4.1. 5-(Hydroxymethyl)-1-[(R)-tetrahydro-2' - oxofur- $3^{\prime}-$ yl)-1Hpyrrole-2-carbaldehyde] (64)

4.2. Funebral (3)

4.3. Pyrrolomorpholine spiroketals

4.4. Methodologies for 2-formylpyrrole synthesis

5. Conclusions

6. Conflicts of interest

7. Acknowledgements

8. Notes and references

\section{Introduction}

5-Hydroxymethylpyrrole-2-carbaldehydes (Fig. 1), sometimes referred to as 2-formylpyrroles or pyrralines, have been isolated from a large array of natural sources, ${ }^{1,2}$ as well as traditional medicine preparations ${ }^{3}$ and cooked foods. ${ }^{4,5}$ Their presence in various thermally-processed products reveals their likely origin - the non-enzymatic Maillard reaction - and to date no

${ }^{a}$ School of Chemical Sciences, University of Auckland, 23 Symonds St, Auckland, 1142, New Zealand. E-mail: m.brimble@auckland.ac.nz; Web: http://www.brimble.chem. auckland.ac.nz

${ }^{b}$ Maurice Wilkins Centre for Molecular Biodiscovery, University of Auckland, Private Bag 92019, Auckland 1142, New Zealand compounds. Regardless of their non-metabolic origin, these compounds exhibit a range of valuable bioactivities including hepatoprotective, ${ }^{6}$ immunostimulatory, ${ }^{7}$ antiproliferative ${ }^{8}$ and antioxidant effects. ${ }^{\mathbf{1 , 9 , 1 0}}$ Furthermore, certain members of this compound family possess highly unique and complex structures, providing attractive targets for total synthesis and the development of novel synthetic methodologies.

This review aims to highlight the interesting biological properties of 2-formylpyrroles and the synthetic methods

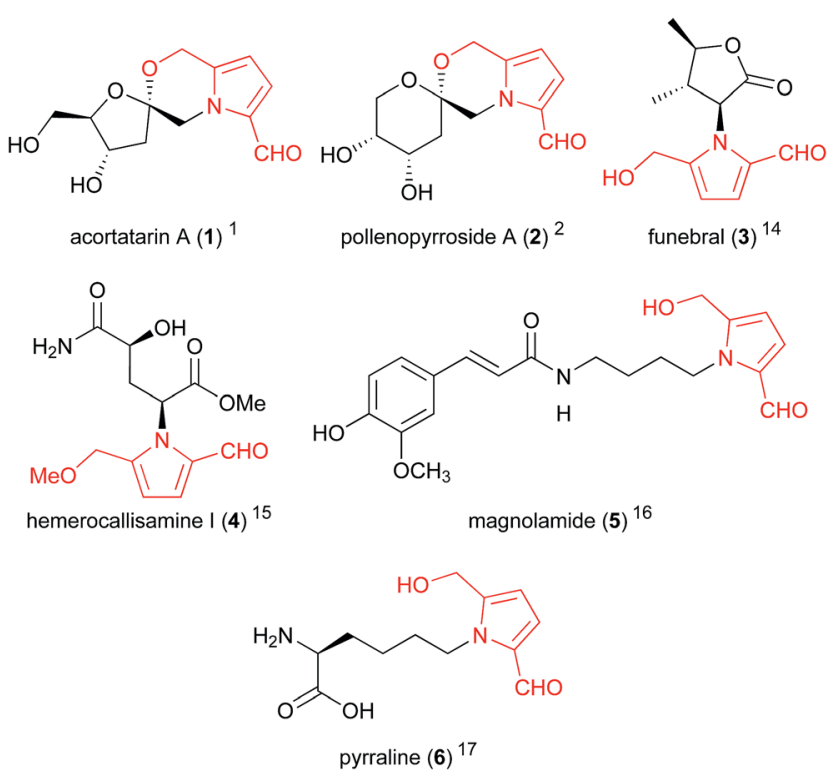

Fig. 1 Representative 2-formylpyrroles (5-hydroxymethylpyrrole-2carbaldehyde system highlighted in red). 
developed to access them. One particular 2-formylpyrrole, the advanced glycation end-product pyrraline (6), will not be discussed here as it has been reviewed recently. ${ }^{11}$ Acortatarin A (1) was reviewed previously by Butler and Aponick, ${ }^{12}$ while a recent review by Shahzad and co-workers ${ }^{13}$ provides a detailed account of the synthetic approaches to acortatarin A (1) and related pyrrolomorpholine spiroketals. These compounds will be discussed herein within the wider context of 2-formylpyrrole natural products.

\section{Non-enzymatic origin}

It has been established that 2-formylpyrroles form in biological systems,${ }^{18}$ yet no enzymatic biosynthesis has been proposed for the 5-hydroxymethylpyrrole-2-carbaldehyde ring system. Rather, it is accepted that these compounds arise from the condensation of amines with sugars in what are commonly

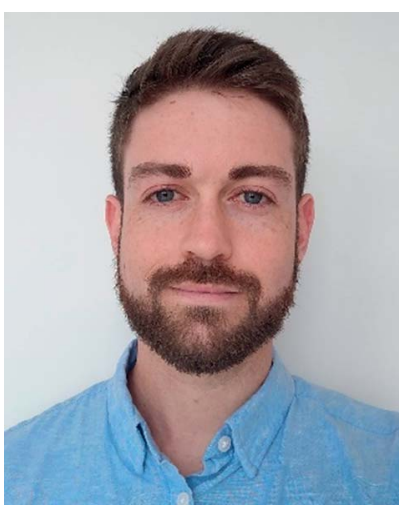

James Wood graduated from the University of Auckland with BSc (Hons) in 2014, before undertaking a PhD with Distinguished Professor Margaret Brimble and Dr Daniel Furkert. His doctoral research concerned the synthesis of 2-formylpyrrole natural products using a Maillard-type reaction. He is currently a research associate at the University of Bristol with Professor John Bower. Areas of interest include the development of new synthetic methods to access bioactive heterocycles and their application in total synthesis and drug discovery.

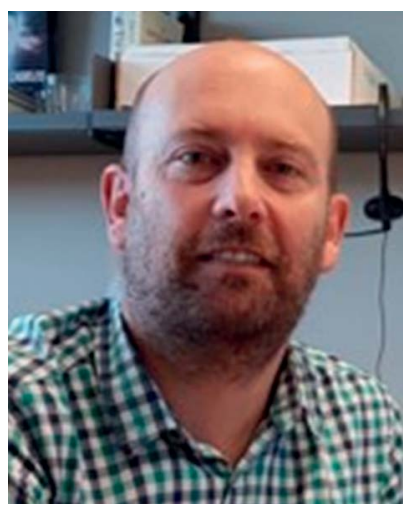

Daniel Furkert is a Senior Research Fellow at The University of Auckland, leading Professor Brimble's natural product synthesis and medicinal chemistry group in the School of Chemical Sciences. After obtaining his undergraduate and doctoral degrees at The University of Auckland, he carried out postdoctoral fellowships in the total synthesis of azaspiracid at Oregon State University (USA), and medicinal chemistry of novel opioid receptor ligands at the University of Bath (UK). He returned to New Zealand take up his current role in 2010, where his current interests include asymmetric synthesis and medicinal chemistry applications of natural products, novel chemical reactivity and drug discovery. referred to as Maillard or browning reactions. ${ }^{19,20}$ This hypothesis stems from the first reports of 2 -formylpyrroles in which these compounds were isolated directly from reaction mixtures of reducing sugars and amines in $1970 .^{21,22}$ Kato and Fujimaki characterised pyrroles $\mathbf{1 3 - 1 5}$ as the reaction products of $\mathrm{D}^{-}$ glucose (7) and methylamine (10), ethylamine (11) or butylamine (12) respectively (Scheme 1). ${ }^{21}$ This reaction was reproducible with hexoses D-galactose (8) and D-fructose (9), albeit with reduced yields.

It is widely proposed that 2-formylpyrroles $\mathbf{2 6}$ arise from the condensation of amines with 3-deoxy-D-glucosone (3-DG) (19) (Scheme 2). ${ }^{23}$ 3-DG (19) is an intermediate in many Maillard reaction pathways and is a degradation product of Amadori compounds, which in turn form by condensation of glucose (7) with amines. ${ }^{20,24,25}$ A number of plausible mechanisms exist for the formation of 2-formylpyrroles 26 from 3-DG (19). It has been suggested that this process is initiated by further dehydration of 3-DG (19) to enone 20 (Scheme 2). ${ }^{23}$ Keto-enol tautomerisation, followed by conjugate addition of an amine affords hemiaminal 22, which undergoes elimination of water. 5-exo-Trig cyclisation gives rise to another hemiaminal species 25, which undergoes elimination of water to form the aromatic pyrrole ring system. ${ }^{26}$

This non-enzymatic synthesis from sugars is quite distinct from most characterised biosynthetic pathways leading to pyrroles, which involve amino acid (glycine, proline, serine, threonine, and tryptophan) and dicarboxylic acid (malonate, oxaloacetate, and succinate) precursors. ${ }^{27}$ It should however be noted that a unique pyrrole biosynthesis from fructose-6phosphate (27) was identified by Lautru and co-workers in 2012, operative in Streptomyces ambofaciens (Scheme 3). ${ }^{28} 4$ Acetamidopyrrole-2-carboxylate (36) was established as a biosynthetic precursor to congocidine (37), a DNA minor groove binder of the pyrrolamide family of natural products. The proposed biosynthetic pathway for 4-acetamidopyrrole-2-

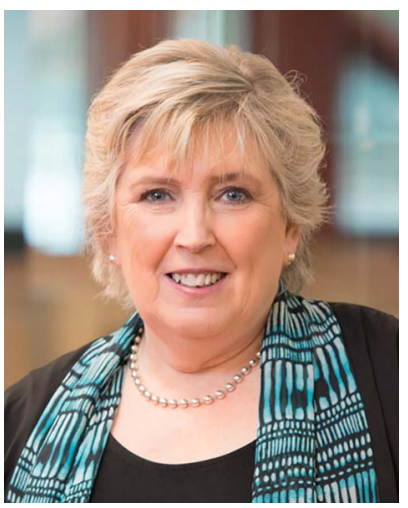

Margaret Brimble is a Fellow of the Royal Society (London) and a Distinguished Professor at the University of Auckland where her research program focuses on the synthesis of bioactive natural products and peptides. She has published $>460$ papers, 65 reviews, holds 30 patents, won the 2018 RSC Sosnovsky Award, 2016 Marsden Medal, 2012 Rutherford Medal (NZ top science award), the 2010 RSC Natural Products Award, named an IUPAC Distinguished Women in Chemistry (2015) and L'Oreal-UNESCO Women in Science laureate for Asia-Pacific, and conferred the Queen's Honour CNZM. She is Past-President of IUPAC Organic and Biomolecular Division III, coFounder of cancer vaccine company SapVax, Associate Editor for Organic and Biomolecular Chemistry, and Past-President of the International Society of Heterocyclic Chemistry. 
<smiles>OC[C@H]1O[C@H](O)[C@@H](O)[C@H](O)[C@H]1O</smiles><smiles>OCC1OC(O)[C@H](O)[C@H](O)[C@H]1O</smiles><smiles>OC[C@H]1O[C@](O)(CO)[C@@H](O)[C@H]1O</smiles>

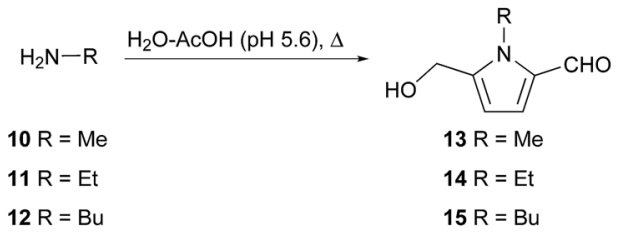

Scheme 1 Synthesis of 2-formylpyrroles from amine and hexose reducing sugar mixtures by Kato and Fujimaki.<smiles>[R]N[C@H]1O[C@H](CO)[C@@H](O)[C@H](O)[C@H]1O</smiles>

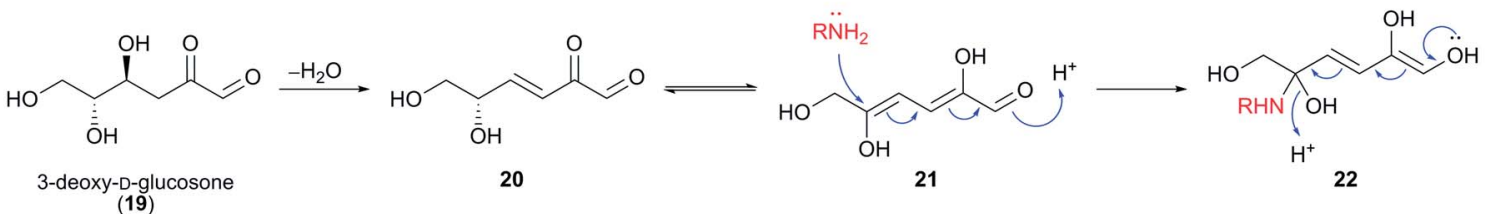<smiles>[R]N/C(=C\C=C(/O)C=O)CO</smiles>

23<smiles>O=CC1CC[18O]CCC(=O)C1</smiles>

24<smiles>C=C</smiles><smiles>[R]C1(CO)CC=C(CO)N1</smiles>

25<smiles>[R]c1ccc(CO)[nH]1</smiles>

26

Scheme 2 Proposed mechanism for the formation of 2-formylpyrroles 26 from amines and D-glucose (7), via 3-deoxy-D-glucosone (19).
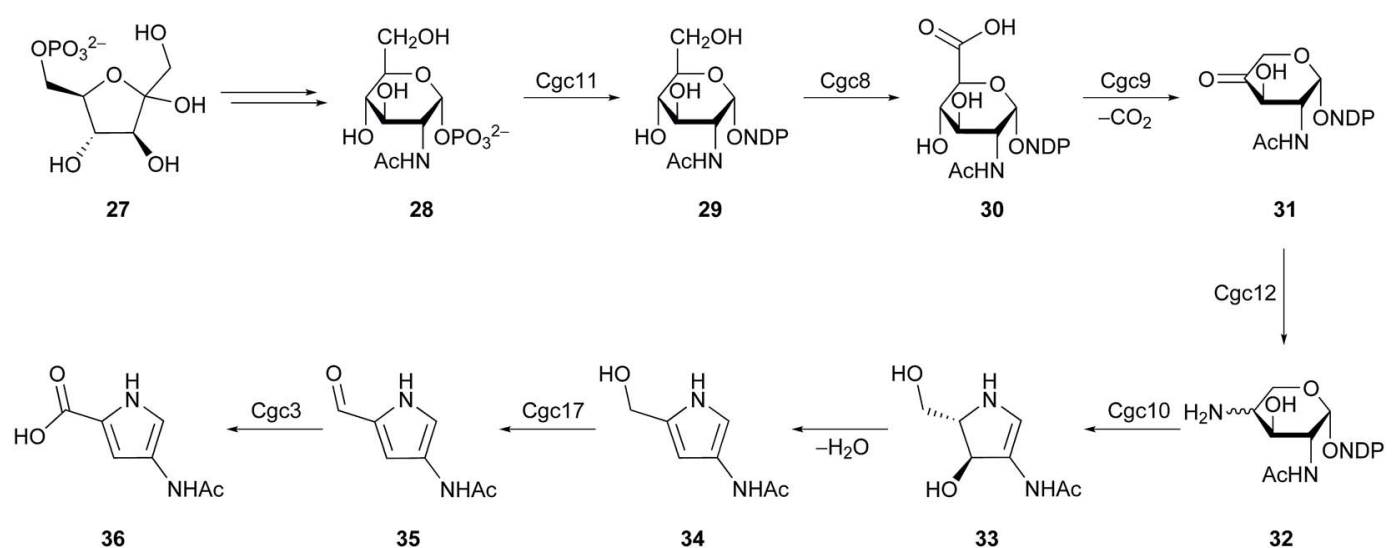

36

35

34

33

32

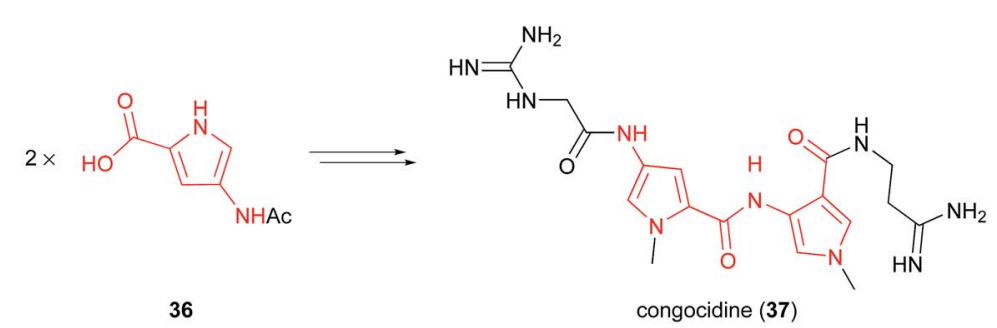

Scheme 3 Proposed biosynthesis of 4-acetamidopyrrole-2-carboxylate (36) from fructose-6-phosphate (27) in Streptomyces ambofaciens. 
carboxylate (36) involves enzymes and precursors from carbohydrate metabolism. The conversion of 4-aminopentose 32 into pyrroline 33 was attributed to Cgc10, an enzyme that resembles a glycosyltransferase. Spontaneous dehydration and subsequent oxidation by a putative alcohol dehydrogenase, Cgc17, delivers 2-formylpyrrole metabolite 35 en route to 4acetamidopyrrole-2-carboxylate (36). This biosynthetic pathway was later extended to the pyrrolamides distamycin and disgocidine in Streptomyces netropsis DSM40846. ${ }^{29}$ It is therefore evident that biosynthetic pathways exist for the conversion of carbohydrates into 2-formyl and 2-carboxylpyrroles, and it remains to be seen whether similar biosynthetic pathways will be characterised for 5-hydroxymethylpyrrole-2-carbaldehydes.

\section{Structural diversity and bioactivity}

2-Formylpyrroles appear frequently in the natural products isolation literature. The sources from which these compounds have been isolated are of limited significance, as no evidence exists for a biosynthetic pathway for these compounds. As such, details of isolation will be minimal, primarily serving to illustrate the ubiquity of 2 -formylpyrroles in nature. This section instead highlights compounds with interesting biological activities and provides an overview of the structural diversity across this compound family. Compounds have been organised into three broad categories according to the type of amine from which they arise: amino acid, biogenic amine or amino sugar.

\subsection{2-Formylpyrroles derived from amino acids}

Compounds which incorporate proteinogenic amino acids represent a major sub-class of 2-formylpyrroles (Fig. 2). Their prevalence reflects the ubiquity of the amino acids from which they arise. As an example of this prevalence, phenylalaninederived lactone 38 has been isolated from flue-cured tobacco, ${ }^{30,31}$ fruit (Celastrus orbiculatus Thunb. (Celastraceae), ${ }^{32}$ Morus alba ${ }^{33}$ ), fungi (Xylaria nigripes ${ }^{34}$ ) and actinobacteria<smiles>O=Cc1ccc2n1[C@@H](Cc1ccccc1)C(=O)OC2</smiles>

$38^{30-36}$

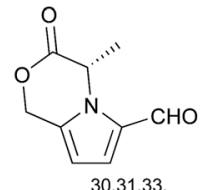

3937,39

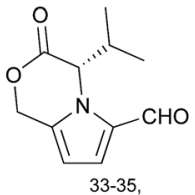

$40^{37,38}$

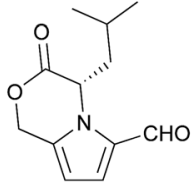

$41^{33-38}$

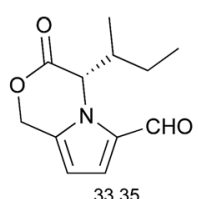

$42^{37,38}$

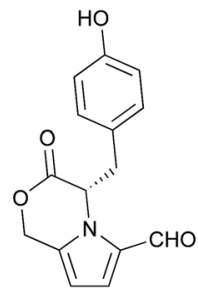

$43^{33,34}$<smiles>[R20]Cc1ccc(C=O)n1CC(=O)O</smiles><smiles>COCc1ccccc1C=O</smiles><smiles>[R20]Cc1ccc(C=O)n1[C@@H](C)C([R20])=O</smiles>

morrole $\mathrm{B}(47)^{33} \quad \mathrm{R}^{1}=\mathrm{R}^{2}=\mathrm{H}$ morrole $C(48)^{33} \quad R^{1}=H, R^{2}=M e$ makomotine $\mathrm{D}(\mathbf{4 9})^{45,46} \mathrm{R}^{1}=\mathrm{Me}, \mathrm{R}^{2}=\mathrm{H}$<smiles>CC(C)[C@H](C(=O)O)n1c(C=O)ccc1CO</smiles><smiles>COCc1ccc(C=O)n1[C@@H](CC(C)C)C(=O)OC</smiles>
$45^{40} \mathrm{R}=\mathrm{Et}$<smiles>[R]OCc1ccc(C=O)n1[C@@H](Cc1ccc(O)cc1)C(=O)OC</smiles>
$\mathbf{5 0}^{33,44} R^{1}=R^{2}=M e$
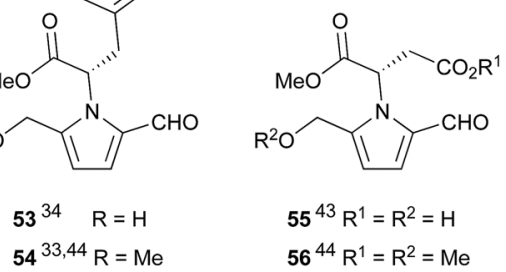

$$
55^{43} \mathrm{R}^{1}=\mathrm{R}^{2}=\mathrm{H}
$$$$
56^{44} R^{1}=R^{2}=M e
$$<smiles>COCc1ccc(C=O)n1[C@@H](CC(N)=O)C(C)=O</smiles>

morrole D (57) ${ }^{33}$<smiles>O=Cc1ccc(CO)n1[C@@H]1CCC(=O)NC1=O</smiles>

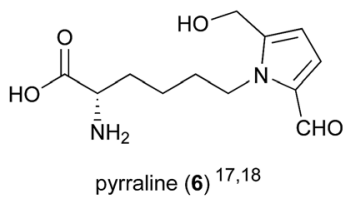<smiles>[R6]Cc1ccc(C=O)n1[C@H]1CC(=O)NC1=O</smiles>

morrole $E(59)^{33} \quad R=M e$<smiles>COCc1ccc(C=O)n1[C@@H](CCC(C)=O)C(C)=O</smiles>

morrole $\mathrm{F}(61)^{33}$

Fig. 2 2-Formylpyrroles derived from proteinogenic amino acids. 
(Jishengella endophytica $161111,{ }^{35}$ Streptomyces albospinus RLe7 (ref. 36)).

Some notable compounds within this 2-formylpyrrole subclass are tyrosine derivative $\mathbf{4 3}$ and alanine derivative $\mathbf{5 0}$ which inhibit porcine pancreatic lipase by $70 \%$ and $40 \%$ respectively at $100 \mu \mathrm{M} .^{33}$ In a separate report, cordyrrole A (62) was also shown to inhibit porcine pancreatic lipase at $100 \mu \mathrm{M}^{\mathbf{4 9}}$ Pancreatic lipase is a target of interest for the development of anti-obesity treatments. Makomotine D (49) has been shown to induce quinone reductase $(\mathrm{QR})$ activity thus enhancing carcinogen detoxification, with a concentration of $43.1 \mu \mathrm{M}$ required to double QR activity. ${ }^{46}$ In the same report, makomotine D (49) was shown to possess hydroxyl radical scavenging ability with an $\mathrm{ED}_{50}$ (concentration for hydroxyl radical scavenging by $50 \%$ ) of $16.7 \mu \mathrm{M}$.

A small number of 2-formylpyrroles comprising unnatural amino acids have also been reported (Fig. 3). Funebral (3) and its Schiff base funebrine (63) were isolated from Quararibea funebris, a flowering tree native to Mexico. ${ }^{\mathbf{1 4 5 0}}$ The plant is used in traditional medicine as a cough remedy, antipyretic, and to control menstrual disorders and psychopathic fears, ${ }^{51}$ although the bioactivity of funebral (3) and funebrine (63) has yet to be evaluated. $\gamma$-Hydroxyisoleucine, the amino acid incorporated in these two compounds, was isolated alongside funebrine $(\mathbf{6 3}) .^{50}$

Homoserine lactone derivative 64 was isolated from 10 dayold Pisum sativum seedlings in $1987 . .^{52}$ The absolute configuration of lactone 64, which corresponds to D-homoserine lactone, was confirmed by total synthesis. The unusual D-homoserine moiety was proposed to arise from opine biosynthetic pathways. Pyrrole 64 was found to inhibit trigonelline-induced cell cycle arrest in $\mathrm{G}_{2}$ phase with an $\mathrm{ED}_{50}$ of $0.5 \mu \mathrm{M}$, signifying the first chemically characterised substance to override hormonally induced cellular arrest in complex tissues. Notably, the synthesised $(S)$-enantiomer of pyrrole 64 was shown to be inactive.

Hemerocallisamine I (4) was isolated from Hemerocallis fulva var. kwanso, $H$. flava, and $H$. minor (daylily flowers) by Matsuda and co-workers in 2014 and again in 2016..$^{15,53}$ Originally assigned as $(2 R, 4 R)-4$ by X-ray crystal structure, the structure of

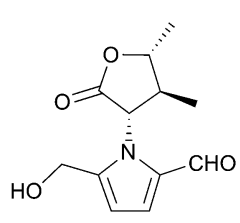

funebral $(3)^{14}$

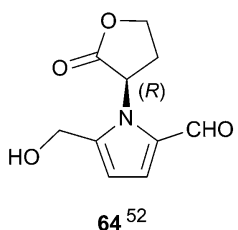

$64^{52}$

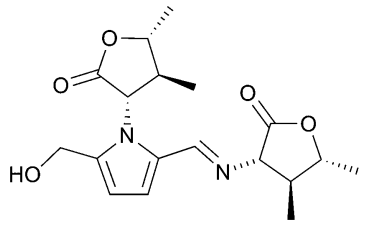

funebrine $(63) 50$

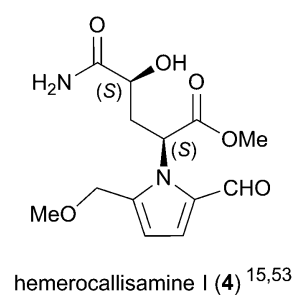

Fig. 3 2-Formylpyrroles derived from non-proteinogenic amino acids. hemerocallisamine I was later revised to the enantiomer $(2 S, 4 S)$ 4 by total synthesis, ${ }^{54}$ suggesting hemerocallisamine I (4) arises from $\mathrm{L}-\gamma$-hydroxyglutamine metabolites in Hemerocallis. A variety of L-glutamine-based metabolites have been isolated from Hemerocallis, ${ }^{55,56}$ some of which inhibit $\alpha \beta 42$ aggregation and accelerate neurite outgrowth in PC12 cells, signifying their potential as novel therapies for Alzheimer's disease. ${ }^{53}$ Hemerocallisamine I (4), however, was shown to lack any such neurological activity.

\subsection{2-Formylpyrroles derived from biogenic amines}

Amino acid decarboxylation products, commonly referred to as biogenic amines, can arise from both the enzymatic decarboxylation of amino acids, as well as the Strecker degradation of amino acids with reducing sugars. ${ }^{20,57}$ The most commonly encountered 2-formylpyrroles within this sub-class are those arising from $\gamma$-aminobutyric acid (GABA), the decarboxylation product of glutamic acid (pyrroles 65-75, Fig. 4). 4-(2-Formyl-5(hydroxymethyl)-1H-pyrrol-1-yl)butanoic acid (PBA) (65) was first isolated from kako-bushi-matsu, a thermally processed Aconitum japonicum root product used in oriental medicine for its analgesic, diuretic and cardiac effects. ${ }^{58}$ PBA (65) has been isolated no fewer than eleven times, ${ }^{4-7,34,41,58-62}$ and its methyl ether 66 no fewer than eight, ${ }^{6-8,34,38,46,63,64}$ from both plant and fungal sources. The yield of PBA (65) from kako-bushi-matsu, which is prepared by autoclaving Aconitum roots at $110{ }^{\circ} \mathrm{C}$, was determined to be 10-fold greater than the yield of PBA (65) from Aconitum roots dried at 50-55 ${ }^{\circ} \mathrm{C} .{ }^{58}$ This observation is consistent with the proposal that PBA is the product of Maillardtype reactions. ${ }^{5}$

PBA (65) and its derivatives possess an impressive array of biological activities. A $50 \mu \mathrm{g}$ dose of PBA (65) caused a significant increase in the peripheral blood flow $(90.3 \pm 18.2 \mathrm{~mL} / 30$ $\mathrm{min} / 100 \mathrm{~g}$ ) of mice. ${ }^{58}$ Free acids PBA (65) and methyl ether 66 were both shown to exhibit hepatoprotective effects at $0.1 \mu \mathrm{M}$ $\left(64.4 \pm 3.9 \%\right.$ and $65.8 \pm 5.6 \%$ cell viability respectively). ${ }^{6}$ The methyl esters $\mathbf{6 7}$ and $\mathbf{6 8}$ also exhibited hepatoprotective effects to a lesser degree, suggesting the importance of the free acid for high hepatoprotective activity. In another report, PBA (65) and methyl ether 66 were shown to possess immunostimulatory activity. ${ }^{7}$ Incubation of RAW 264.7 macrophage cells with PBA (65) resulted in a significant increase in phagocytotic activity, while methyl ether 66 caused a smaller increase in activity and morrole A (70) had no effect. It was supposed that the 5hydroxymethyl moiety was important for macrophage stimulatory activity as increasingly large substitution at this position corresponded with decreased activity.

PBA methyl ether 66 was found to inhibit rat lens aldose reductase with an $\mathrm{IC}_{50}$ of $39.71 \pm 1.77 \mu \mathrm{M} .{ }^{63}$ Aldose reductase is the first enzyme in the polyol pathway of glucose metabolism. Increased flux through this pathway can cause diabetic complications including retinopathy, neuropathy, nephropathy and cataracts. Methyl ether 66 also exhibits moderate antiproliferative activity, inhibiting four different human tumour cell lines; A459, SK-OV-3, SK-MEL-2 and HCT-15, with an $\mathrm{IC}_{50}$ range of $21.52 \pm 1.82 \mu \mathrm{M}$ to $40.74 \pm 2.41 \mu \mathrm{M}{ }^{8}$ The cancer 


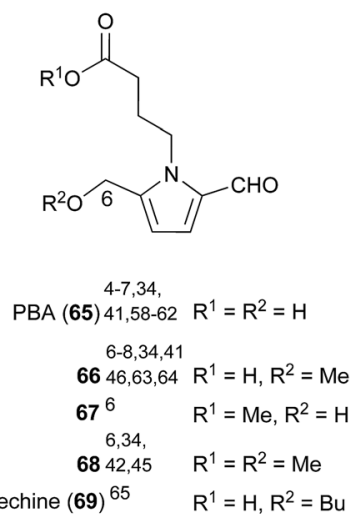<smiles>COc1cc(/C=C/C(=O)NCCCCn2c(C=O)ccc2CO)ccc1O</smiles>

magnolamide (5) ${ }^{16}$

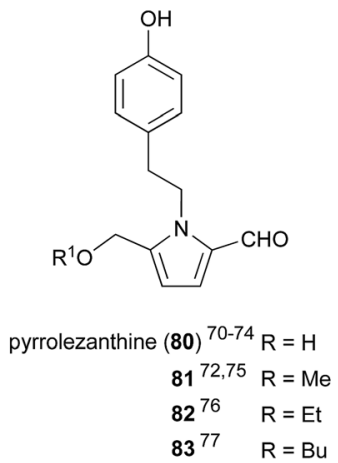

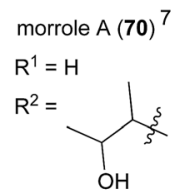

ranunculin $\mathrm{C}(74)^{67}$

$\mathrm{R}^{1}=\mathrm{H}$

$R^{2}=u\left(\sigma^{\prime}\right.$

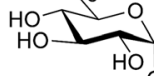

$\mathrm{O}_{\mathrm{OH}}^{\mathrm{OH}}$

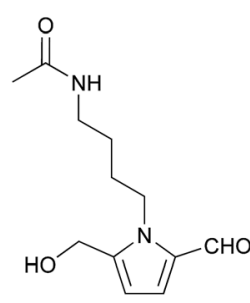

$76^{68}$

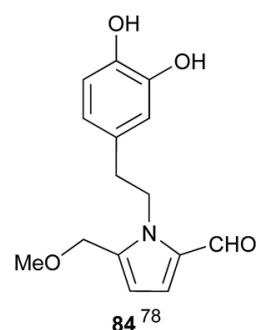

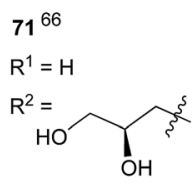

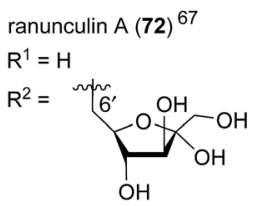

ranunculin $\mathrm{B}(73)^{67}$

$\mathrm{R}^{1}=\mathrm{H}$

$R^{2}=$ up
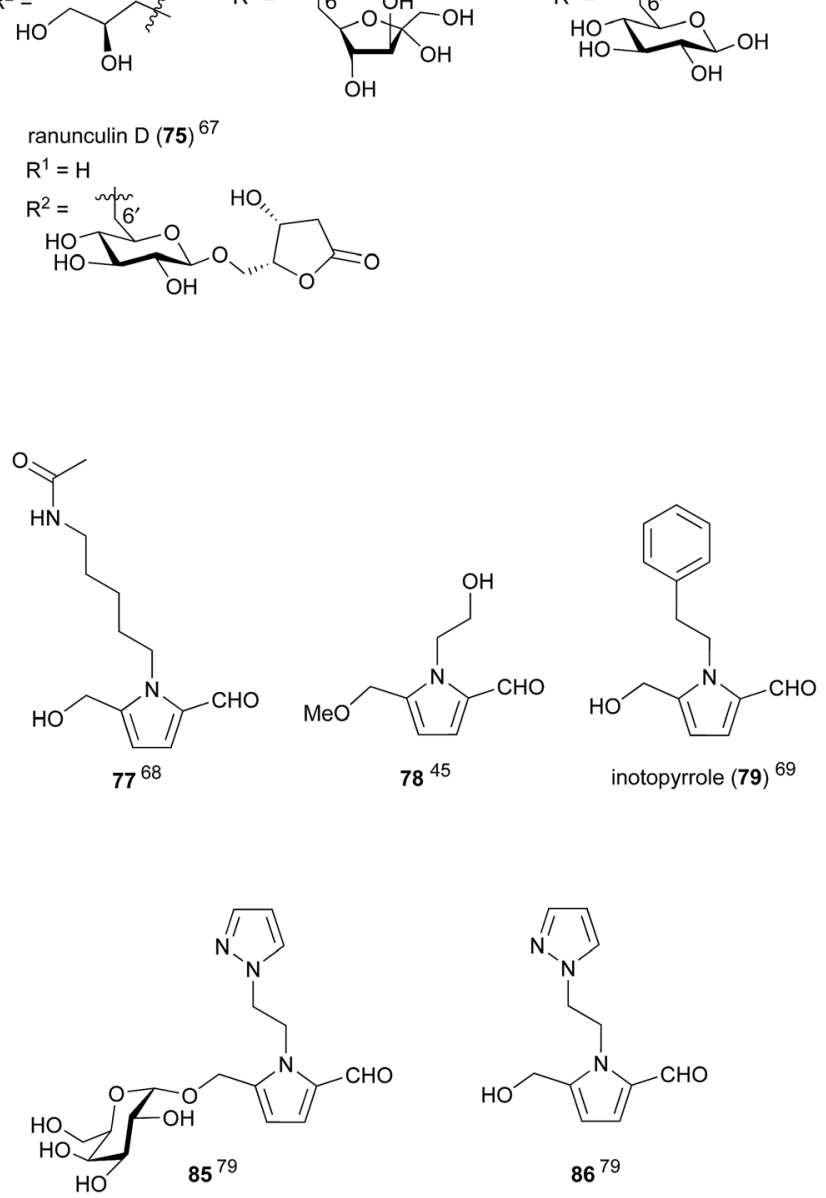

Fig. 4 2-Formylpyrroles derived from biogenic amines.

chemopreventative properties of PBA methyl ether 66 were investigated and it was found to exhibit hydroxyl radical scavenging activity. ${ }^{46} \mathrm{PBA}$ methyl ester $\mathbf{6 6}$ was also shown to induce quinone reductase $(\mathrm{QR})$ with a concentration of $2.4 \mu \mathrm{M}$ required to double QR activity.

Ranunculins A-D (72-75) were recently isolated from the roots of Ranunculus ternatus Thunb, a plant used in traditional Chinese medicine. ${ }^{67}$ While no bioactivity was investigated for these four GABA-derived pyrroles, they contain an unprecedented 6-6' ether link between the pyrrole hydroxymethyl substituent, putatively arising from C-6 of 3-DG (19), and the C-6 carbons of fructose (ranunculin A (72)) or glucose (ranunculins B-D (73-75)). This tail-tail ether connectivity has not been observed in any other natural products, whereas head-head (e.g. trehalose: 1,1 connected), head-tail (e.g. isomaltose: 1,6 connected) and head-body (e.g. sucrose: 1,2 connected) connectivities are all well-known. Attempts to synthesise these natural products by 6-6' ether formation between PBA (65) and the appropriate sugar derivatives were unsuccessful.
Magnolamide (5), which contains trans-feruloyl and putrescine moieties, was shown to possess antioxidant activity, inhibiting $\mathrm{Cu}^{2+} / \mathrm{O}_{2}$-induced LDL lipid peroxidation with an $\mathrm{IC}_{50}$ of $9.7 \pm 2.8 \mu \mathrm{M} .{ }^{9}$ This was comparable to the positive control resveratrol $\left(\mathrm{IC}_{50} 13.1 \pm 2.6 \mu \mathrm{M}\right)$. Putrescine and cadaverinederived pyrroles 76 and 77 showed weak activity against human cancer cell lines HeLa, K-562 and L-929, with IC $_{50}$ values ranging between $8.9-20.2 \mu \mathrm{g} \mathrm{mL} \mathrm{m}^{-1}$, but were inactive against the microbes Bacillus subtilis, Staphylococcus aureus, Escherichia coli, and Candida albicans $\left(\mathrm{IC}_{50}>10 \mu \mathrm{g} \mathrm{mL}{ }^{-1}\right){ }^{68}$

Tyramine derivative pyrrolezanthine (80) was found to exhibit moderate cytotoxicity against lung cancer A-549 and human colon cancer SW480 cell lines with $\mathrm{IC}_{50}$ values of 38.3 and $33.7 \mu \mathrm{M}$ respectively. ${ }^{74}$ Pyrrolezanthine (80) was also demonstrated to possess anti-inflammatory activity, inhibiting NO production in RAW 264.7 macrophage cells with an $\mathrm{IC}_{50}$ of $58.8 \mu \mathrm{M} .{ }^{73}$ Pyrrolezanthine butyl ether 83, which was isolated from the butanol soluble fraction of Reynoutria ciliinervis (Nakai) Moldenke extract, was found to possess antifungal 
activity against Sclerotinia sclerotiorum with a MIC of $31.2 \mu \mathrm{g}$ $\mathrm{mL}^{-1} \cdot 77$

Pyrroles 85 and 86 were isolated from watermelon (Citrullus lanatus) seeds in 2015. ${ }^{79}$ They were the first compounds containing both pyrazole and pyrrole rings to be isolated from a natural source and are likely derived from $\beta$-(1-pyrazolyl) alanine, a non-proteinogenic amino acid produced in watermelon.

\section{3. $\quad \mathrm{N}$-Unsubstituted 2-formylpyrroles derived from amino sugars}

A small sub-class of 2-formylpyrroles exist with no $\mathrm{N}$-substituents (Fig. 5). These compounds plausibly arise from the selfcondensation of hexosamines. Interestingly, $O$-D-galactopyranoside 94 appears to arise either from a disaccharide precursor, or<smiles>O=Cc1ccc(COC(=O)CCCO)[nH]1</smiles><smiles>[R]Cc1ccc(C=O)[nH]1</smiles>

$\begin{array}{rl}7,69 & \\ 88 & 82,83 \quad R=H\end{array}$ $89^{35,84} \mathrm{R}=\mathrm{Me}$ $90^{85} \quad \mathrm{R}=\mathrm{Et}$

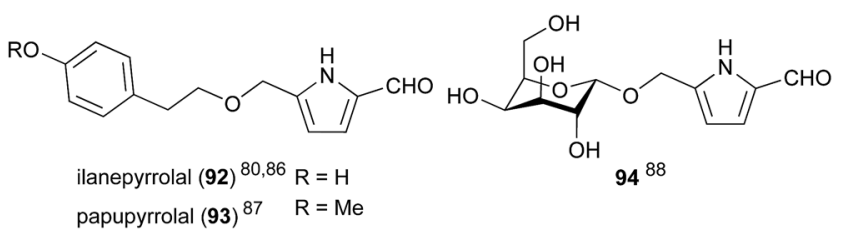

Fig. $5 \mathrm{~N}$-Unsubstituted 2-formylpyrroles. hemerocallisamine II (91) ${ }^{15,53} \mathrm{R}=\mathrm{Bu}$ from the glycosylation of 2 -formylpyrrole 88 . Of these $\mathrm{N}$-unsubstituted 2-formylpyrroles, only ilanepyrrolal (92) was shown to exhibit biological activity. Ilanepyrrolal (92), which was isolated from rice fermented with the endophytic fungus Annulohypoxylon ilanense (Xylariaceae), was demonstrated to inhibit Mycobacterium tuberculosis growth with a MIC value of $76.8 \mathrm{mM}^{80}$

\subsection{Pyrrolomorpholine spiroketals derived from amino sugars}

Another small group of amino sugar derivatives, referred to as pyrrolomorpholine spiroketals (Fig. 6), are thought to arise from the intermolecular condensation of 3-DG (19) with 1amino-1,3-dideoxy-D-fructose (95) (acortatarin A (1), pollenopyrroside A (2), shensongine B (97) and shensongine A (98)) or 1-amino-1-deoxy-D-fructose (100) (acortatarin B (101) and shensongine C (102)). ${ }^{5}$ 3-DG (19) is a deamination product of Amadori compounds, while 1-amino-1-deoxyhexoses are the products of Strecker degradation. Both processes are associated with Maillard pathways. The generation of pyrrolomorpholine spiroketals by a Maillard pathway was proposed by Jiang and Peterson, who isolated acortatarin A (1) and a [6,6]pyrrolomorpholine spiroketal, the stereochemistry of which was not determined, from bread., ${ }^{4,5}$ These compounds were present in higher concentrations in the bread crust, which is exposed to the highest temperatures during baking, supporting this Maillard hypothesis. ${ }^{4}$ There are regioisomeric [5,6]spiroketals and [6,6]-spiroketals within this group of compounds depending on which hydroxy group of 1-amino-1,3dideoxy-D-fructose (95) is engaged in spirocyclisation. For each regioisomer there are two possible configurations at the spiroketal center giving rise to pairs of spiroketal anomers.

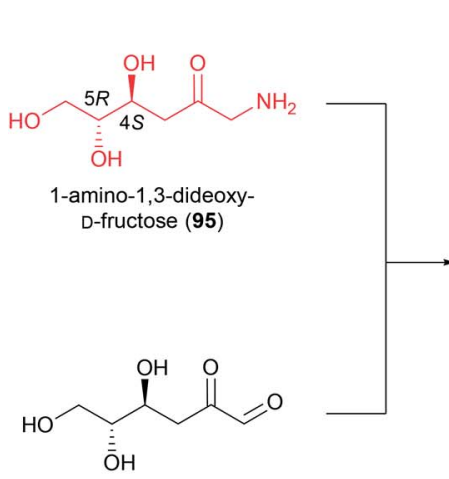

3-deoxy-D-glucosone (19)

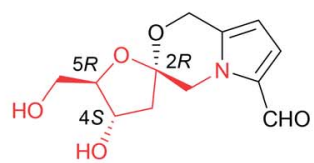

acortatarin $A(1)^{1-5,89}$

(pollenopyrroside $\mathrm{B}$ )

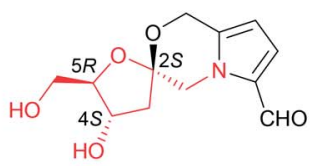

shensongine $B(97)^{3,89}$ (xylapyrroside B)

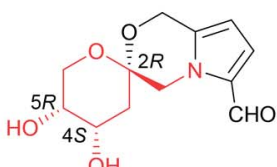

$\overline{\mathrm{OH}}$

pollenopyrroside $\mathrm{A}(2)^{2,89}$

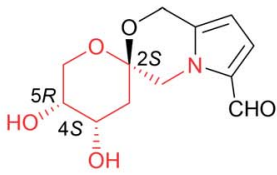

shensongine A (98) ${ }^{3,89}$ (xylapyrroside A)

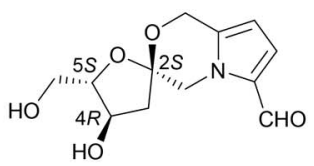

capparisine A (96) ${ }^{39}$

ent-(1)

proposed

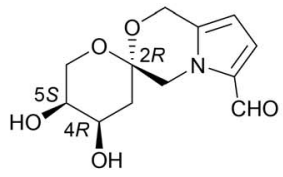

ent-(98)

proposed

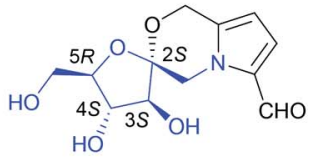

shensongine $\mathrm{C}(\mathbf{1 0 2})^{3}$ capparisine B (99) ${ }^{39}$

Fig. 6 Pyrrolomorpholine spiroketals. 
Pyrrolomorpholine spiroketals first appeared in the literature in 2010 when three reports of their isolation emerged independently of each other., ${ }^{1,239}$ Three different trivial naming systems were subsequently proposed in these reports, a problem which would later be compounded by the isolation of additional pyrrolomorpholine spiroketals. In addition to bread crust, these spiroketals have been isolated from the rhizomes of Acorus tatarinowii, ${ }^{1}$ beecollected Brassica campestris pollen, ${ }^{2}$ fruits of Capparis spinosa, ${ }^{39}$ the traditional Chinese medicine preparation Shensong Yangxin, ${ }^{3}$ and the fermented mycelia of Xylaria nigripes. ${ }^{89}$ All of these pyrrolomorpholine spiroketals are derived from D-sugars, with the exception of capparasines A (96) and B (99), the absolute stereochemistry of which was proposed from X-ray crystal structure. ${ }^{39}$ While this enabled unambiguous assignment of the relative stereochemistry of capparisines A and B, insufficient evidence was provided for the assignment of the absolute stereochemistry of these two compounds, which are likely to be the misassigned structures of acortatarin A (1) and shensongine A (98), respectively.

Pyrrolomorpholine spiroketals inhibit the high glucoseinduced production of reactive oxygen species (ROS) in mesangial cells. High glucose-induced ROS production is implicated in diabetic nephropathy, the leading cause of end-stage renal disease in the Western world..$^{90}$ ROS-inhibition was originally established for acortatarin A (1) and B (101), ${ }^{1}$ however Verano and Tan later demonstrated that all members of the pyrrolomorpholine spiroketal family inhibit high glucose-induced ROS production. ${ }^{11}$ Acortatarin A (1) and shensongine C (102) are the most active of the isolated compounds, with $\mathrm{IC}_{50}$ values of 4.6 and $4.8 \mu \mathrm{M}$ respectively and a maximum inhibition of ROS production of 100\%. The synthetic analogues 103 and 104 are the most potent pyrrolomorpholine spiroketals tested to date (Fig. 7), with $\mathrm{IC}_{50}$ values of 0.52 and $0.27 \mu \mathrm{M}$ respectively, however they can only effect $80 \%$ and $60 \%$ maximum inhibition of ROS production.
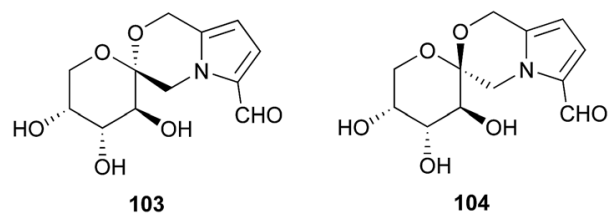

Fig. 7 Synthetic analogues of the pyrrolomorpholine spiroketals with improved inhibition of high glucose-induced ROS production.
A report by Nie and co-workers in 2013 elucidated the biological action of acortatarin A (1). ${ }^{\mathbf{1 0}}$ Pre-incubation of rat glomerular mesangial cells with acortatarin A (1) attenuates high-glucose phosphorylation of PKC isoforms PKC $\alpha$ and $\mathrm{PKC} \beta 1, \mathrm{PLC} \gamma 1$ and the p85 regulatory subunit of PI3K. Inhibition of the PI3K-PLC $\gamma 1$-PKC signalling pathway, which is an upstream regulator of NADPH oxidase activation, inhibits high glucose-induced ROS production. In turn, inhibition of high glucose-induced ROS production prevents overproduction of extracellular matrix proteins by mesangial cells, which has been closely correlated with deterioration of renal function.

In addition to their effects on high glucose-induced ROS production, shensongine A (98) and C (102) were found to shorten action potential duration in rat myocardial cells, with noticeable effects at concentrations as low as $1 \mu \mathrm{M}^{3}$ It was speculated that shensongine A (98) and C (102) might either inhibit L-type calcium channels, or facilitate the action of potassium channels.

\section{Synthesis}

Aside from the isolation of 2-formylpyrroles as minor products in amine-sugar reaction mixtures, efforts have been dedicated towards the selective synthesis of these compounds. Many of these syntheses employ the Paal-Knorr reaction to form pyrrole ring systems around readily available amines, while other approaches involve $N$-alkylation of a pyrrole substrate (Scheme 4 ). Both of these strategies often involve late stage modification of the pyrrole ring substituents in order to furnish the 5-hydroxymethylpyrrole-2carbaldehyde system. More recently, Maillard chemistry-inspired methodologies have been developed to forge the 5hydroxymethylpyrrole-2-carbaldehyde ring system cleanly in a single step from amines and sugars, or sugar surrogates. This section will focus on the total syntheses of 5-(hydroxymethyl)-1- $[(R)$ tetrahydro-2'-oxofur-3'-yl)-1 $H$-pyrrole-2-carbaldehyde] (64), funebral (5) and the pyrrolomorpholine spiroketals, which best encompass the different synthetic strategies towards 2-formylpyrroles.

\subsection{5-(Hydroxymethyl)-1- $\left[(R)\right.$-tetrahydro- $2^{\prime}$-oxofur- $\left.3^{\prime}-\mathrm{yl}\right)-1 H$ - pyrrole-2-carbaldehyde] (64)}

The first total synthesis of a 2-formylpyrrole was reported in conjunction with the isolation and biological evaluation of 5-

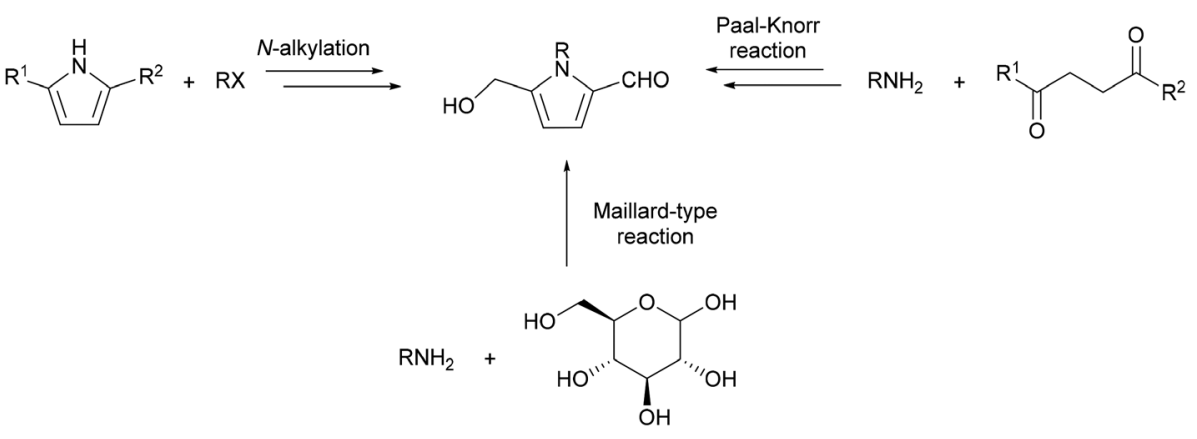

Scheme 4 Different synthetic approaches to the 5-hydroxmethylpyrrole-2-carbaldehyde system. 
(hydroxymethyl)-1-[(R)-tetrahydro-2'-oxofur-3'-yl)-1H-pyrrole-2carbaldehyde] (64) by Lynn and co-workers in 1987 (Scheme 5). ${ }^{52}$ The pyrrole ring system was constructed by the Paal-Knorr reaction of D-homoserine lactone (105) and 2,9-dimethyldeca-2,8-dien4,7-dione (106), which proceeded with some racemisation of the $\alpha$-stereocentre. Ozonolysis of bis(isobutenyl)pyrrole 107 and selective reduction of the resultant biscarbaldehyde with diborane afforded 2-formylpyrrole 64. This Paal-Knorr strategy has since been employed in many syntheses of 2-formylpyrroles.

A racemic synthesis of 2-formylpyrrole 64 was reported by Neier and co-workers in 1993 (Scheme 6). ${ }^{\mathbf{9}}$ This synthesis also employed a Paal-Knorr condensation, using asymmetric dione equivalent $\mathbf{1 1 0}$ to enable a different end-game approach to the 5-hydroxymethylpyrrole-2-carbaldehyde system. Dione equivalent 110 was obtained by oxidation of 2-methylfuran (108) and subsequent hydrogenation of dihydrofuran 109 using RANEY® nickel. The Paal-Knorr condensation of dione equivalent 110 with rac-homoserine lactone (105) proceeded in excellent yield. Vilsmeier-Haack formylation and oxidation of the 5-methyl substituent with lead(Iv) acetate afforded acetate 113, hydrolysis of which furnished 2-formylpyrrole 64 .

\subsection{Funebral (3)}

Funebral (3) has been the subject of four different total syntheses to date. While it shares a high degree of structural similarity to the cellular arrest inhibitor 5-(hydroxymethyl)-1$[(R)$-tetrahydro-2'-oxofur-3'-yl)-1 $H$-pyrrole-2-carbaldehyde] (64), funebral (3) has no known bioactivity. Interest in this compound has been driven largely by the synthetic challenge posed by the three contiguous stereocenters of its $\gamma$-butyrolactone ring and the sterically crowded pyrrole ring.
The first total synthesis of $( \pm)$-funebral (3) and ( \pm )-funebrine 63 was reported by Le Quesne and co-workers in 1995, ${ }^{93-95}$ which utilised 2,9-dimethyldeca-2,8-dien-4,7-dione (106) to construct the pyrrole ring from $\alpha$-amino- $\gamma$-butyrolactone 120 (Scheme 7). Racemic $\alpha$-amino- $\gamma$-butyrolactone 120 was afforded in $14 \%$ yield over eight steps, which included a diastereoselective Claisen rearrangement and iodolactonisation. Synthesis of the sterically crowded bis(isobutenyl)pyrrole 121 by Paal-Knorr condensation of $\alpha$-amino- $\gamma$-butyrolactone 120 and dione 106 required titanium(Iv) isopropoxide to proceed. ( \pm )-Funebral (3) was afforded from bis(isobutenyl)pyrrole 121 by osmiumcatalysed oxidative olefin cleavage and monoreduction. Treatment of $( \pm$ )-funebral (3) with excess $\alpha$-amino- $\gamma$-butyrolactone 120 provided $( \pm)$-funebrine 63 .

The first enantioselective synthesis of funebral (3) and funebrine (63) was reported by Ishibashi and co-workers in 2003 (Scheme 8). ${ }^{96}$ Their preparation of $(-)-\alpha$-amino- $\gamma$-lactone 120 involved a [2,3]-cycloaddition of $(E)$-crotyl alcohol (115) with nitrone 124, which in turn was derived from methyl glyoxylate (123) and an oxime 122 bearing an L-gulose-based chiral auxiliary. Cleavage of the auxiliary and translactonisation provided lactone 126 in excellent yield, which was elaborated to $\alpha$-amino$\gamma$-lactone 120. Funebral (3) and funebrine (63) were accessed via the same strategy employed by Le Quesne and co-workers ${ }^{93}$ with further optimisation of reaction conditions. Interestingly, the Paal-Knorr conditions reported by Le Quesne and co-workers were not reproducible and titanium(Iv) ethoxide was instead employed as a Lewis acid catalyst in this key step.

Sakaguchi and co-workers reported a synthesis of funebral (3) and funebrine (63) in 2011, utilising dione 129 for the PaalKnorr reaction of $\alpha$-amino- $\gamma$-lactone 120 (Scheme 9). ${ }^{97}$ Dione 129 was prepared over five steps from hydroxymethylfurfural

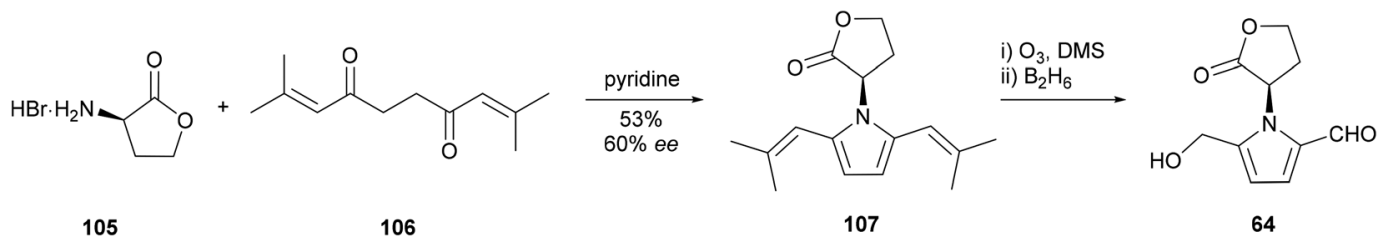

Scheme 5 Synthesis of 5-(hydroxymethyl)-1-[(R)-tetrahydro-2'-oxofur-3'-yl)-1H-pyrrole-2-carbaldehyde] (64) by Lynn and co-workers (yields omitted where not given).

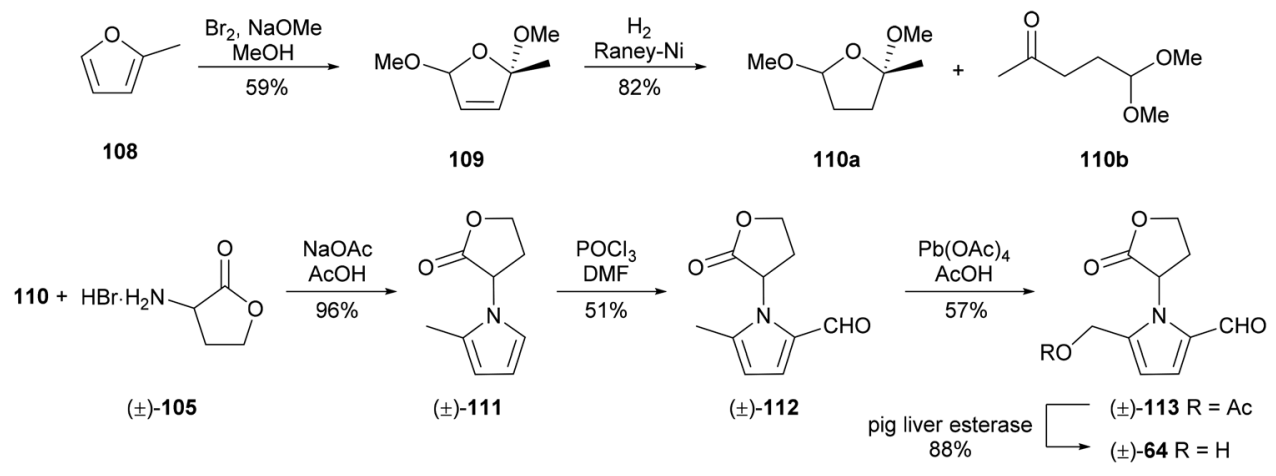

Scheme 6 Synthesis of 5-(hydroxymethyl)-1-[(R)-tetrahydro-2'-oxofur-3'-yl)-1H-pyrrole-2-carbaldehyde] (64) by Neier and co-workers. 


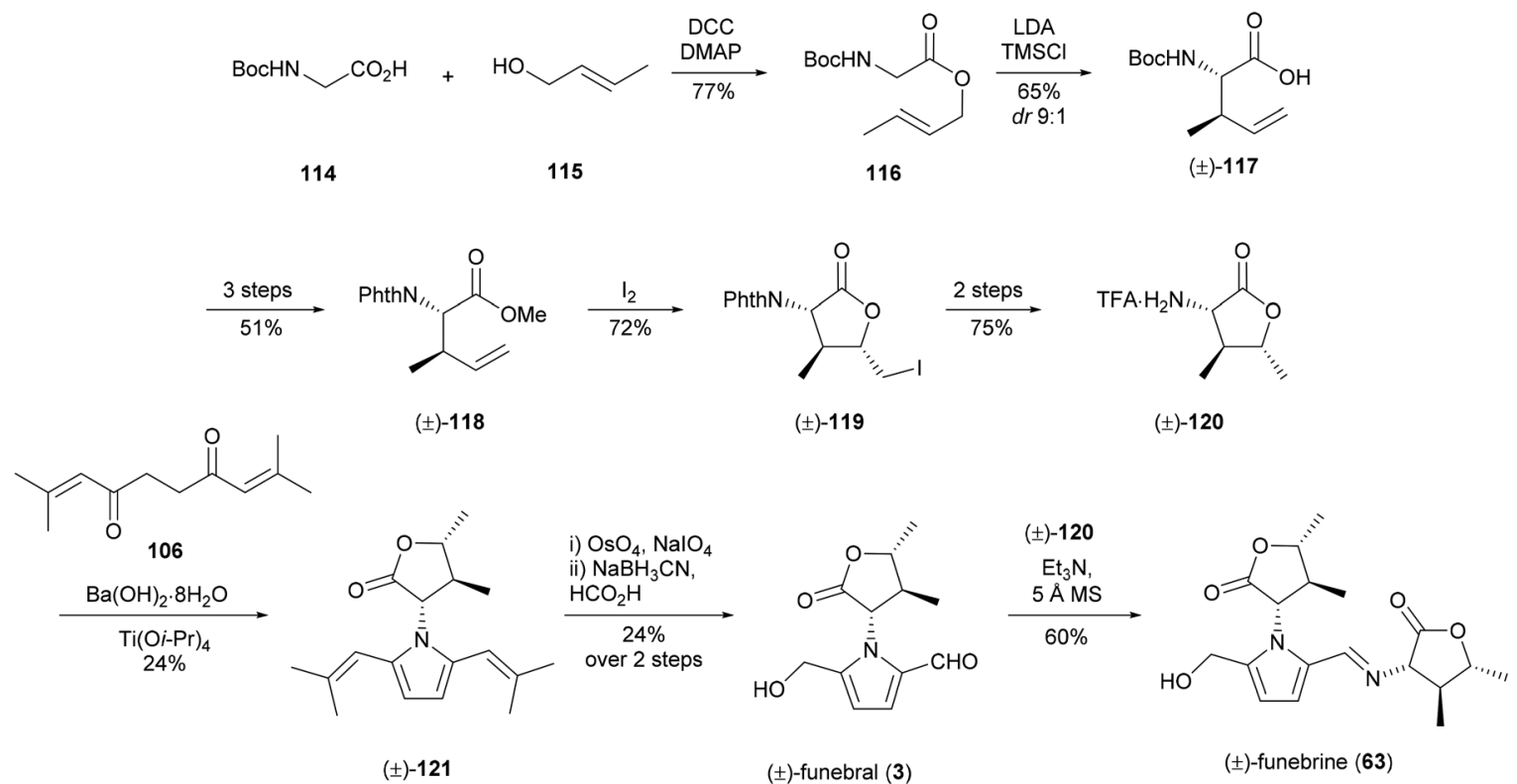

Scheme 7 Racemic synthesis of funebral (3) and funebrine (63) by Le Quesne and co-workers.

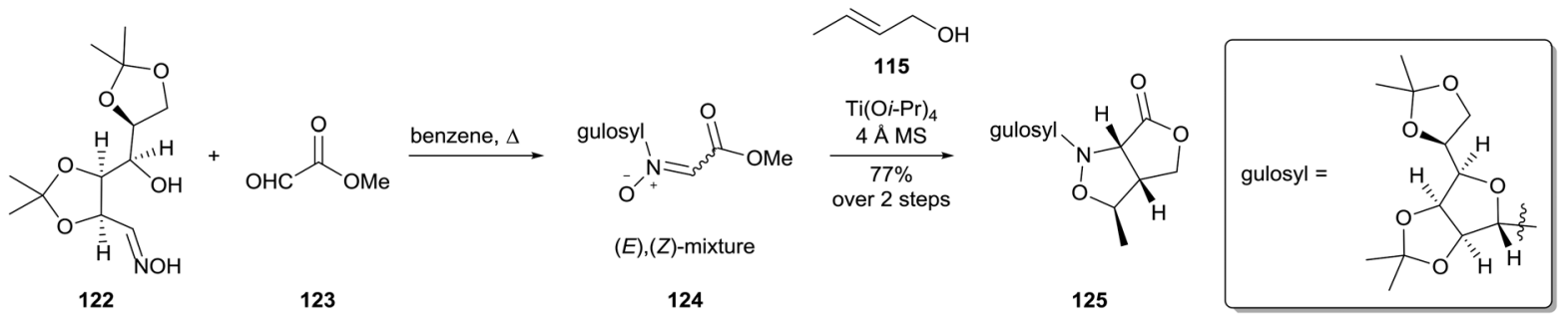<smiles>CC(C)=CC(=O)CCC(=O)C=C(C)C</smiles>
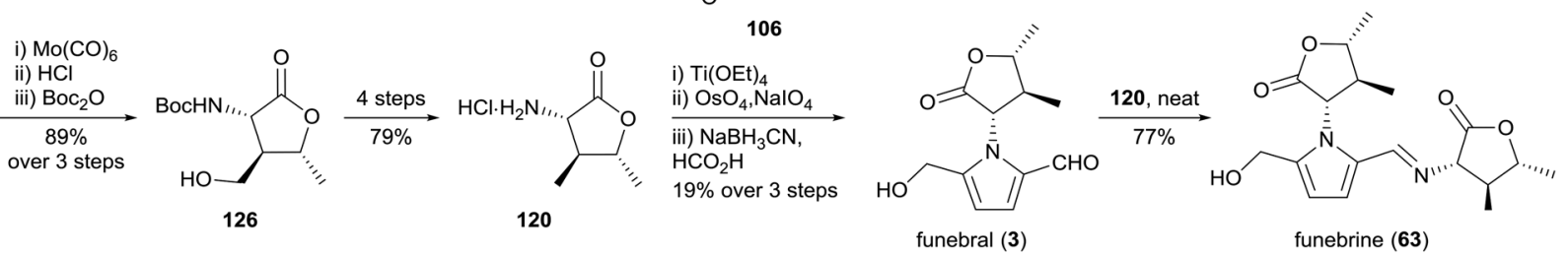

Scheme 8 Enantioselective synthesis of funebral (3) and funebrine (63) by Ishibashi and co-workers.

(127), while $\alpha$-amino- $\gamma$-lactone 120 was prepared from 2-butyn1-ol (130) and Boc-glycine over ten steps which included a diastereoselective Claisen rearrangement of propargyl ester 131 and gold(I)-catalysed cyclisation of the resultant allenylsilane 132. The Paal-Knorr reaction of amine $\mathbf{1 2 0}$ with dione $\mathbf{1 2 9}$ provided pyrrole 134, oxidation of which afforded access to funebral (3) and funebrine (63) in good yield.

In 2014, Brimble and co-workers reported a concise synthesis of funebral (3) by a Maillard-type condensation approach, which forged the pyrrole substituents in the correct oxidation state (Scheme 10). ${ }^{\mathbf{9 8}} \alpha$-Amino- $\gamma$-butyrolactone $\mathbf{1 2 0}$ was prepared by an L-proline-catalysed Mannich reaction of ethyl glyoxal-derived imine 137 with 2-butanone. $\alpha$-Amino- $\gamma$ - butyrolactone 120 was afforded as a $1: 1$ mixture of diastereomers by sodium borohydride reduction. Dihydropyranone 140, which had previously been prepared by the group, ${ }^{99}$ underwent condensation with four equivalents of amine $\mathbf{1 2 0}$ to provide TBS-protected funebral 141a, along with its diastereomer 141b and funebrine-type adducts 142. Desilylation of TBS-protected adduct 141a afforded funebral (3) in a longest linear sequence of six steps.

\subsection{Pyrrolomorpholine spiroketals}

In 2011, Sudhakar and co-workers reported the first total synthesis of acortatarin A (1) and B (101) (Scheme 11). ${ }^{\mathbf{1 0 0}}$ 


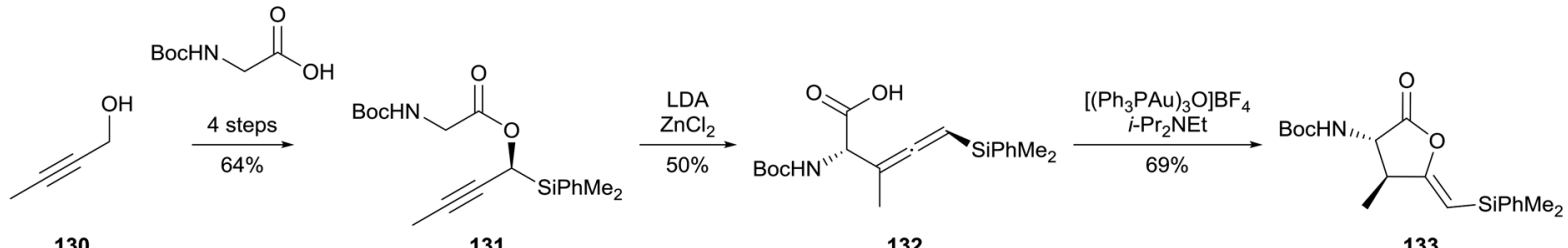

130
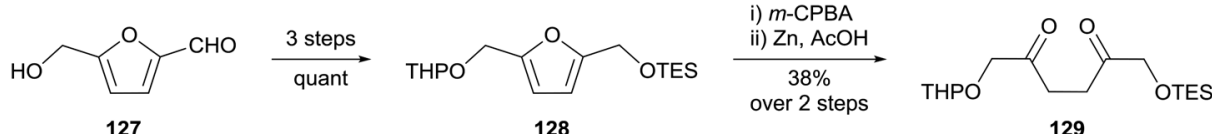

129
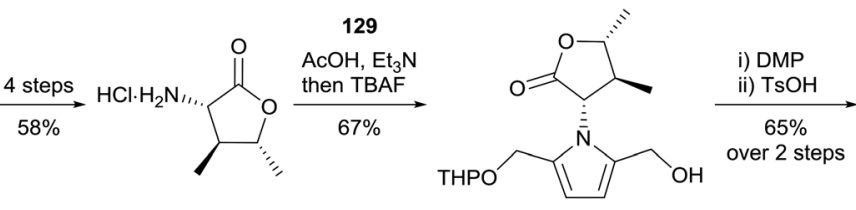

120

134

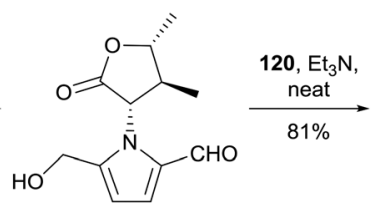

funebral (3)

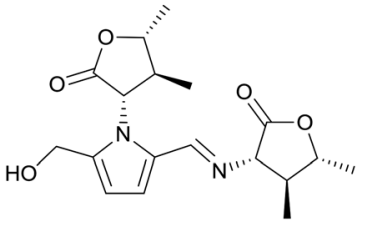

funebrine (63)

Scheme 9 Synthesis of funebral (3) and funebrine (63) by Sakaguchi and co-workers.

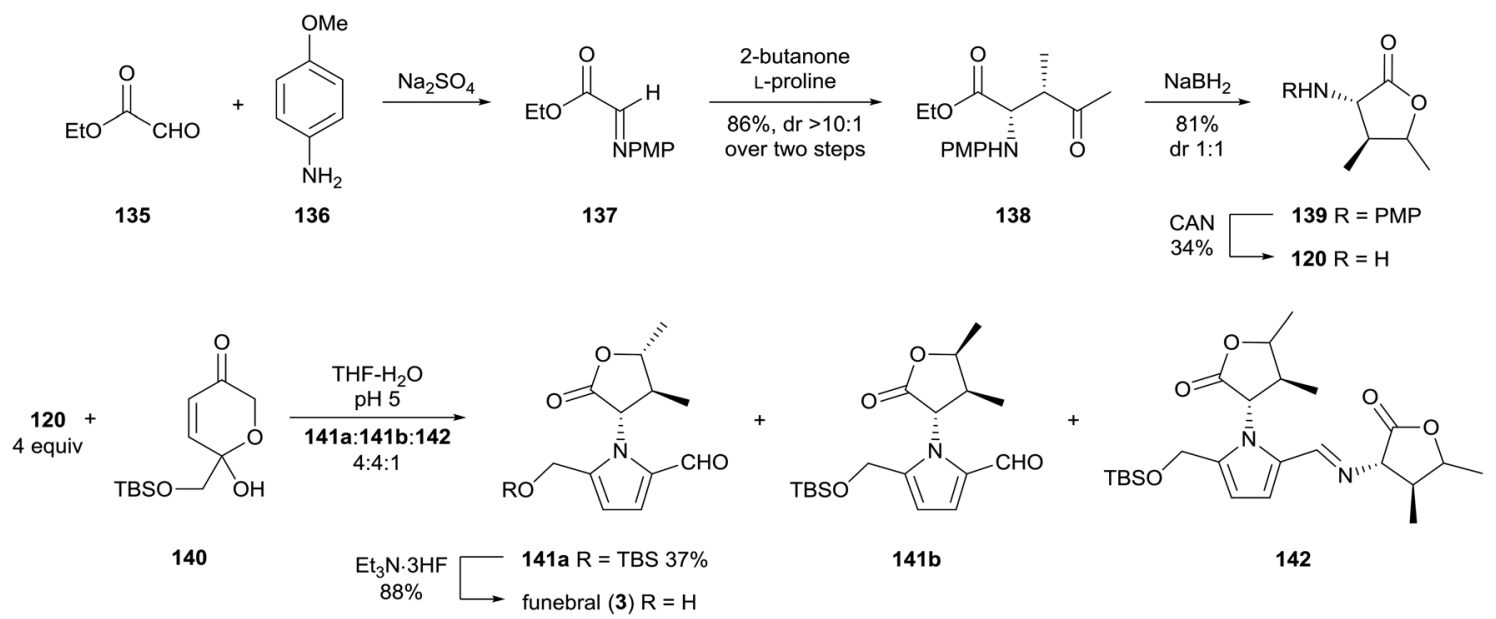

Scheme 10 Synthesis of funebral (3) by Brimble and co-workers.

Incidentally, the acid-catalysed spiroketalisation conditions used also afforded the anomers of the acortatarins; shensongine B (97) and C (102), preceding their isolation from natural sources by three years. The synthesis strategy employed 2-deoxyD-ribose and D-arabinose as chiral pool materials. Homologation and epoxidation of these sugars provided electrophiles for $N$-alkylation of pyrrole 149, which had the requisite aldehyde and hydroxymethyl substituents already installed. Oxidation of secondary alcohols 150 and 151, deprotection and acidcatalysed spirocyclisation afforded $\alpha$-spiroketal anomers acortatarin A (1) and shensongine $\mathrm{C}(\mathbf{1 0 2})$ as major products, while $\beta$-spiroketal anomers shensongine B (97) acortatarin B (101) were afforded in minor quantities. The efficiency of this approach would inspire later syntheses of pyrrolomorpholine spiroketals by the groups of Kuwahara ${ }^{101}$ and $\mathrm{Hu}^{89}{ }^{89}$ which both used THP-protected pyrrole carbaldehyde 149.
Brimble and co-workers utilised a Maillard-type approach to synthesise acortatarin A (1) in 2012 (Scheme 12). ${ }^{99,102}$ Dihydropyranone 140, which would be used to construct the pyrrole ring system of acortatarin A (1), was prepared by Achmatowicz rearrangement of furfuryl alcohol 155, which in turn was prepared from furfuryl silyl ether 154. Homoallylic alcohol 157 was obtained by the known allylation of $(R)$-glyceraldehyde derivative 156. Subsequent protecting group manipulations and functional group interconversions provided aminohydrin 159, which underwent condensation with dihydropyranone 140 to afford TBS-protected adduct 160 . Oxidation of alcohol 160, acidcatalysed spirocyclisation and deprotection then furnished acortatarin A (1) as the major product along with $\beta$-anomer shensongine $B(97)$ in a diastereomeric ratio of $3: 2$.

Brimble and co-workers employed the same synthetic strategy to access pollenopyrroside A (2) in 2016 (Scheme 13). ${ }^{103}$ 


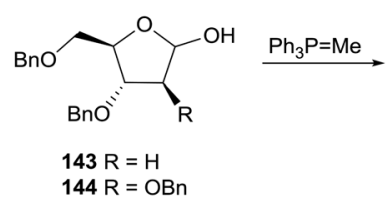

$144 \mathrm{R}=\mathrm{OBn}$

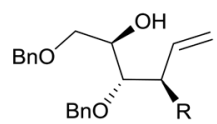

$145 \mathrm{R}=\mathrm{H} 63 \%$ $146 \mathrm{R}=\mathrm{OBn} 78 \%$ i) TBSOTf, lutidine ii) $m$-CPBA<smiles>[2H]C([18OH])C([18OH])[C@H]([18OH])[13CH]1CO1</smiles>

$147 \mathrm{R}=\mathrm{H} 66 \%$

$148 \mathrm{R}=\mathrm{OBn} 70 \%$

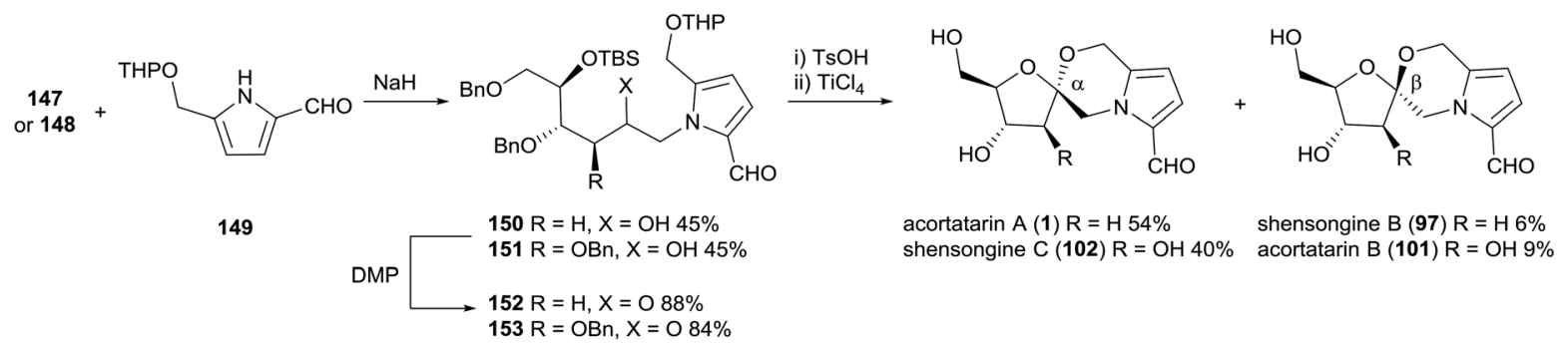

Scheme 11 Synthesis of acortatarins A (1) and B (101) and shensongines B (97) and C (102) by Sudhakar and co-workers.
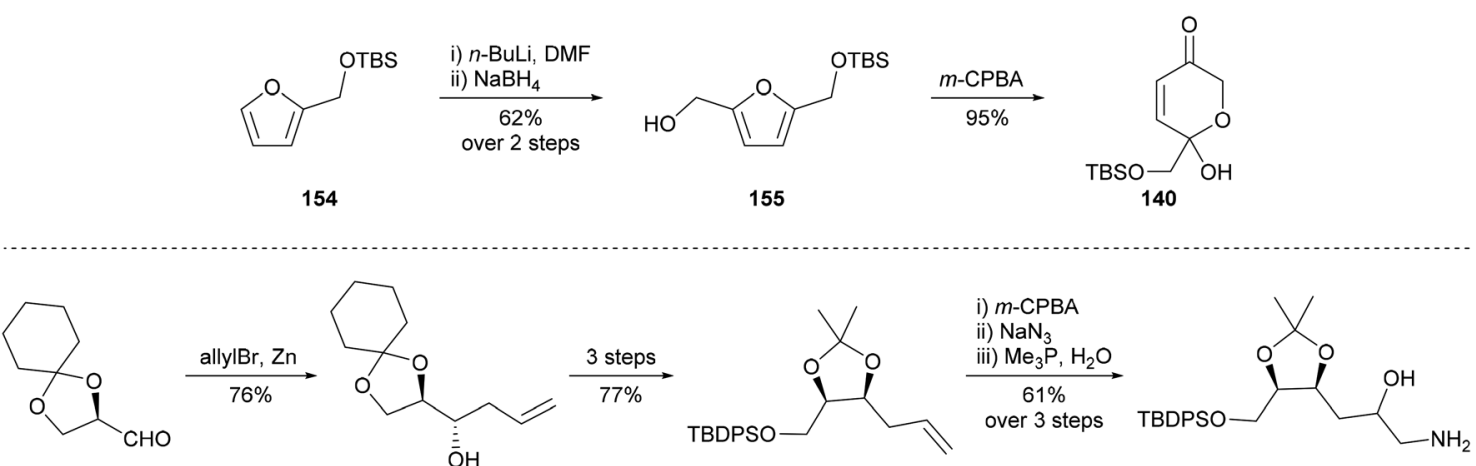

156

157

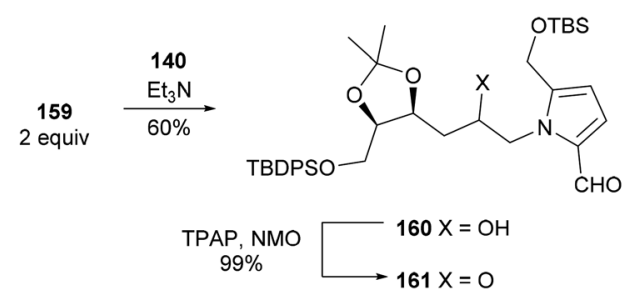

158

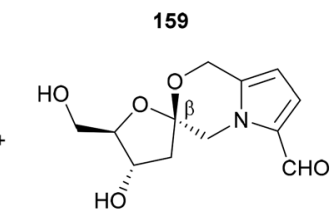

acortatarin $A(1) 37 \%$

shensongine $B(97) 22 \%$

Scheme 12 Synthesis of acortatarin A (1) and shensongine B (97) by Brimble and co-workers.

The Maillard-type condensation of amine 162, which was accessed in six steps from 2-deoxy-D-ribose, proved challenging and required the more reactive acetylated dihydropyranone 163 to proceed. Oxidation, silyl ether deprotection and spiroketalisation provided two [6,6]-spiroketal anomers with little diastereoselectivity. Deprotection of the acetonide protecting group with pyridinium para-toluenesulfonate in methanol resulted in concomitant epimerisation of the spiroketal ring, favouring pollenopyrroside A (2) over shensongine A (98) in a $7: 1$ ratio.

Tan and co-workers reported a synthesis of acortatarins A (1) and B (101), and shensongine B (97) in 2012, using D-thymidine (167) as a chiral pool starting material (Scheme 14). ${ }^{\mathbf{1 0 4}}$ The carbon skeleton of the natural products was forged by a highyielding alkylation of pyrrole-2,5-dicarbaldehyde (170) with iodomethylglycal 169. The [5,6]-spiroketal core of acortatarin A
(1) was prepared diastereoselectively by mercury-mediated oxidative cyclisation of the hydroxymethyl pyrrole substituent onto the gycal, followed by borohydride reduction of the mercurial adduct. Deprotection of each anomer gave acortatarin A (1) and shensongine B (97), respectively. From the common glycal intermediate 171, acortatarin B (101) was prepared by diastereoselective $\beta$-epoxidation using DMDO, followed by a one pot reduction of the pyrrole-2,5-dicarbaldehyde and spirocyclisation onto the epoxide.

Verano and Tan reported a follow-up synthesis of the $[6,6]-$ pyrrolomorpholine spiroketals shensongine A (98) and pollenopyrroside A (2) in 2017 using a similar $N$-alkylation of pyrrole2,5-dicarbaldehyde (170) (Scheme 15). ${ }^{91}$ It was noted that biphasic conditions were required for the $N$-alkylation to prevent dimerization of pyrrole species. Monoreduction of dicarbaldehyde 174, treatment with catalytic Brønsted acid and 


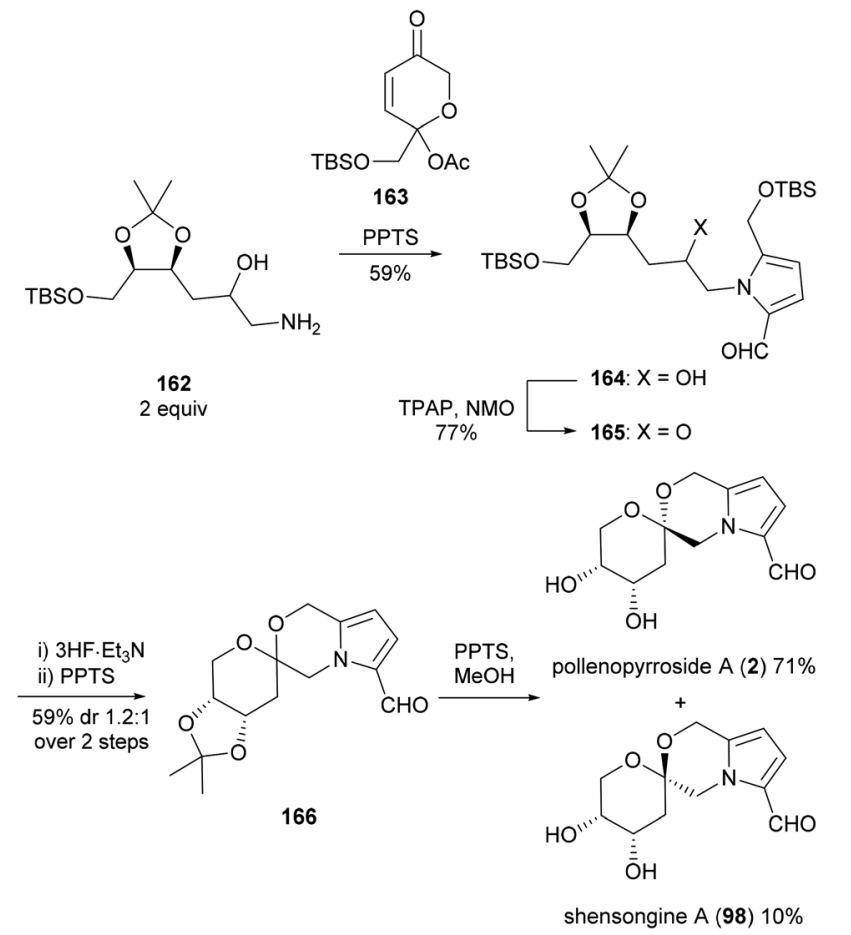

Scheme 13 Synthesis of pollenopyrroside A (2) and shensongine A (98) by Brimble and co-workers.

silyl deprotection afforded shensongine A (98) exclusively. Stereoselective synthesis of pollenopyrroside A (2) was achieved by anti-epoxidation and methanol-catalysed spirocyclisation of glycal epoxide 174, affording the kinetic $\alpha$-spiroketal anomer 175. Barton-McCombie deoxygenation and desilylation provided pollenopyrroside A (2).

Borrero and Aponick reported a total synthesis of acortatarin A (1) and shensongine B (97) in 2012, featuring a palladium(II)- catalysed allylic transposition reaction developed within the group (Scheme 16). ${ }^{\mathbf{1 0 5}}$ Bromoketone 177 was synthesised over seven steps from known $\delta$-hydroxyester 176, which in turn was derived from $\mathrm{L}$-tartrate. Union of 5-formylpyrrole-2-carboxamide 178 and bromoketone 177 proceeded best with caesium carbonate, which supressed competing elimination of the benzyloxy group. Reduction of pyrrole carbaldehyde 179 and treatment with bis(benzonitrile)palladium(II) chloride resulted in allylic transposition, forging the [5,6]-spiroketal system as a mixture of anomers 180 and 182. The terminal olefins 180 and 182 were advanced separately, both affording acortatarin A (1) as the major product upon titanium(Iv) chloride-catalysed benzyl cleavage.

Zhao and co-workers reported a synthesis of shensongine A (98) and pollenopyrroside A (2) in 2015 (Scheme 17). ${ }^{\mathbf{1 0 6}}$ The synthetic strategy involved functionalisation of pyrrole 184, the synthesis of which had been described in an earlier publication by the group from pyrrole and D-fructose. ${ }^{107} \mathrm{~A}$ microwaveaccelerated protocol was developed to enable efficient bishydroxymethylation of pyrrole 184, with subsequent $\mathrm{MnO}_{2}$ oxidation affording the pyrrole-2,5-dicarbaldehyde 185. Protecting group manipulations, followed by selective reduction of one carbaldehyde group gave 2-formylpyrrole 186, which underwent acid-catalysed cyclisation to provide a $3: 1$ mixture of $\beta$-anomer 187 and $\alpha$-anomer 188. These two spiroketals were advanced separately to shensongine A (98) and pollenopyrroside A (2) by modified Barton-McCombie deoxygenation and benzyl deprotection.

In 2017, Pale and co-workers reported a novel synthesis of acortatarin A (1) and shensongine B (97) which showcased the utility of zeolite-based organic synthesis (Scheme 18). ${ }^{\mathbf{1 0 8}}$ Five of the eleven steps in the synthesis were performed using native or metal-doped zeolite catalysts. The acortatarin skeleton was assembled by ynamide coupling of alkynyl bromide 192 and pyrrole 193. This reaction was catalysed by copper(I)-doped<smiles>Cc1cn([C@H]2C[C@H](O)[C@@H](CO)O2)c(=O)[nH]c1=O</smiles>

167

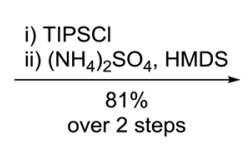

over 2 steps<smiles>O=CC1=CC=[Te+2]C(C=O)=C1</smiles>
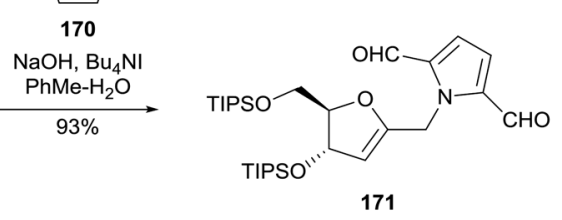

i) $\mathrm{NaBH}_{4}$

ii) NaHDMS, $\mathrm{Hg}(\mathrm{OAc})_{2}$ then $\mathrm{NaBH}_{4}$ iii) TBAF

$93 \%$

171
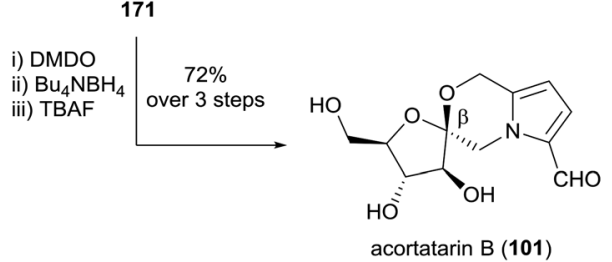

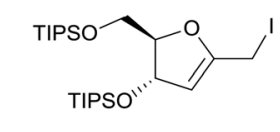

169

168

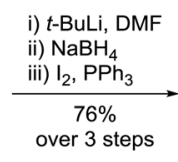

Scheme 14 Synthesis of acortatarins A (1) and B (101) and shensongine B (97) by Tan and co-workers. 


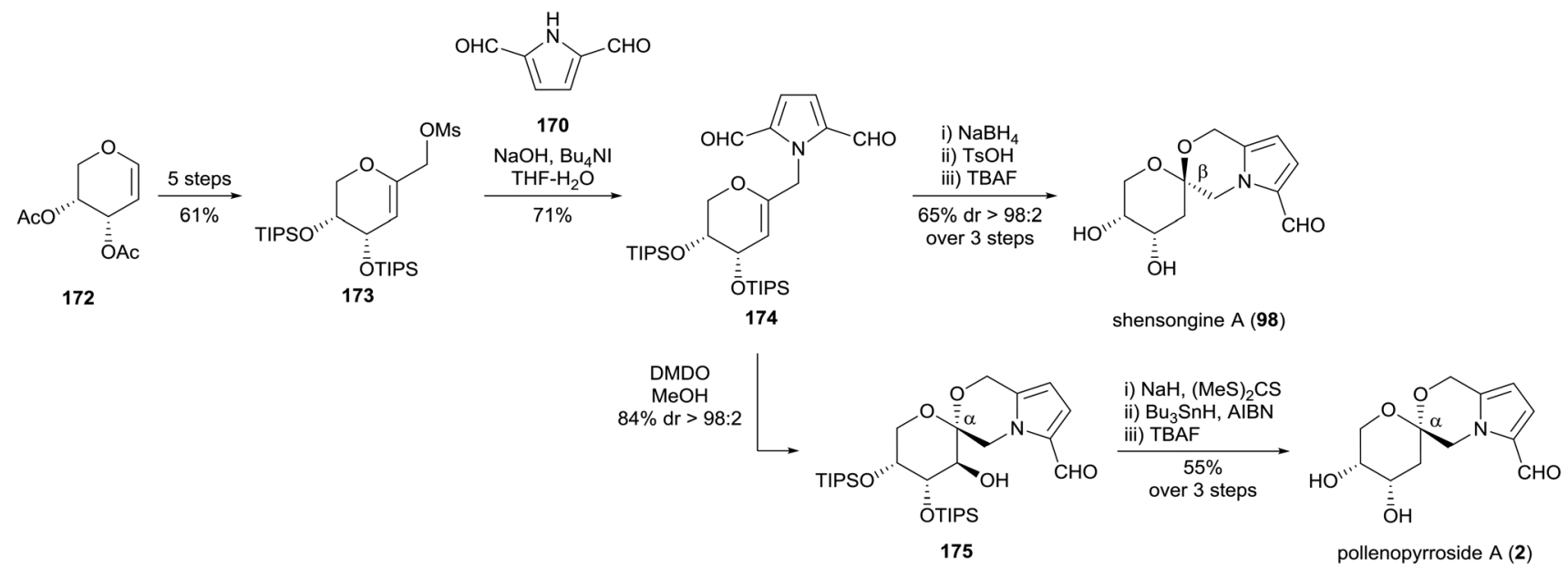

Scheme 15 Synthesis of shensongine A (98) and pollenopyrroside A (2) by Verano and Tan.

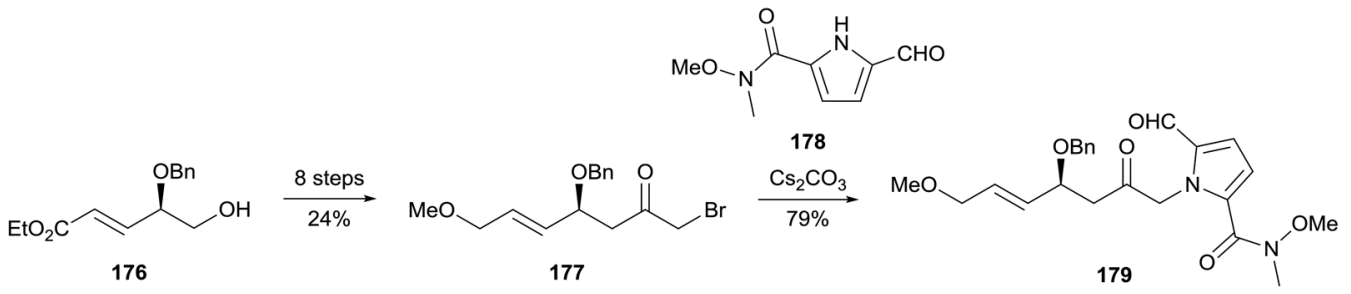

177

179

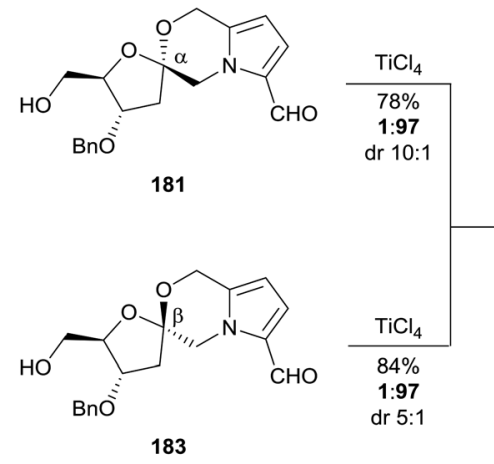

183

dr $5: 1$

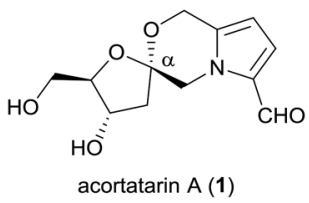

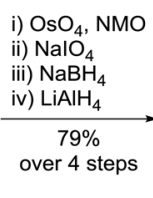

\begin{tabular}{l} 
i) $\mathrm{OsO}_{4}, \mathrm{NMO}$ \\
ii) $\mathrm{NalO}_{4}$ \\
iii) $\mathrm{NaBH}_{4}$ \\
iv) $\mathrm{LiAlH}_{4}$ \\
\hline $79 \%$ \\
over 4 steps
\end{tabular}

182
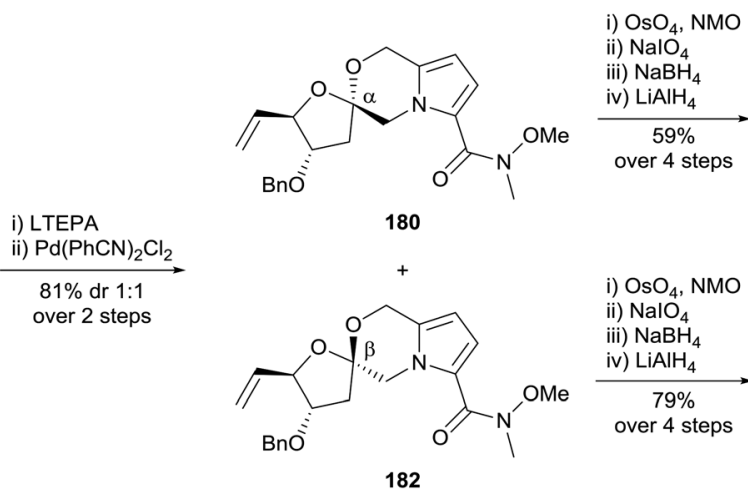

Scheme 16 Synthesis of acortatarin A (1) and shensongine B (97) by Borrero and Aponick.

zeolite, which performed better than both homogenous copper catalysts, and polystyrene and mesoporous silica-based heterogeneous copper catalysts. Sequential silver-catalysed alkyne hydroxylation and acid-catalysed cyclisation afforded spiroketal 196 as an anomeric mixture. The end-game synthesisstrategy involved redox manipulations to install the pyrrole carbaldehyde substituent and benzyl deprotection, providing acortatarin A (1) and shensongine B (97) as a $3: 1$ mixture of anomers.

\subsection{Methodologies for 2-formylpyrrole synthesis}

In addition to the considerable efforts towards the total synthesis of complex 2-formylpyrroles, two recent methodology studies have explored the reaction of sugars with amines to deliver synthetically useful yields of 2-formylpyrroles. In 2015, Koo and co-workers reported conditions for the synthesis of 2formylpyrroles directly from various hexose reducing sugars and amines (Scheme 19). ${ }^{109}$ This Maillard-type reaction was performed in dimethylsulfoxide at $90{ }^{\circ} \mathrm{C}$ with one equivalent of oxalic acid to facilitate dehydration of D-glucose (7) in the presence of the basic amine substrates. These conditions were used to form the 2-formylpyrroles of a variety of amines as well as the lactonised pyrrole adducts $\mathbf{3 8}$ and $\mathbf{3 9}$ of L-phenylalanine methyl ester (198) and L-alanine methyl ester (199), respectively. The Maillard-type reaction of D-glucose (7) and $\gamma$-aminobutyric acid methyl ester (200) enabled access to lobechine (69) in three steps.

In 2016, Zhao and co-workers reported conditions for the synthesis of oxazine-fused pyrroles from amino acids and D- 


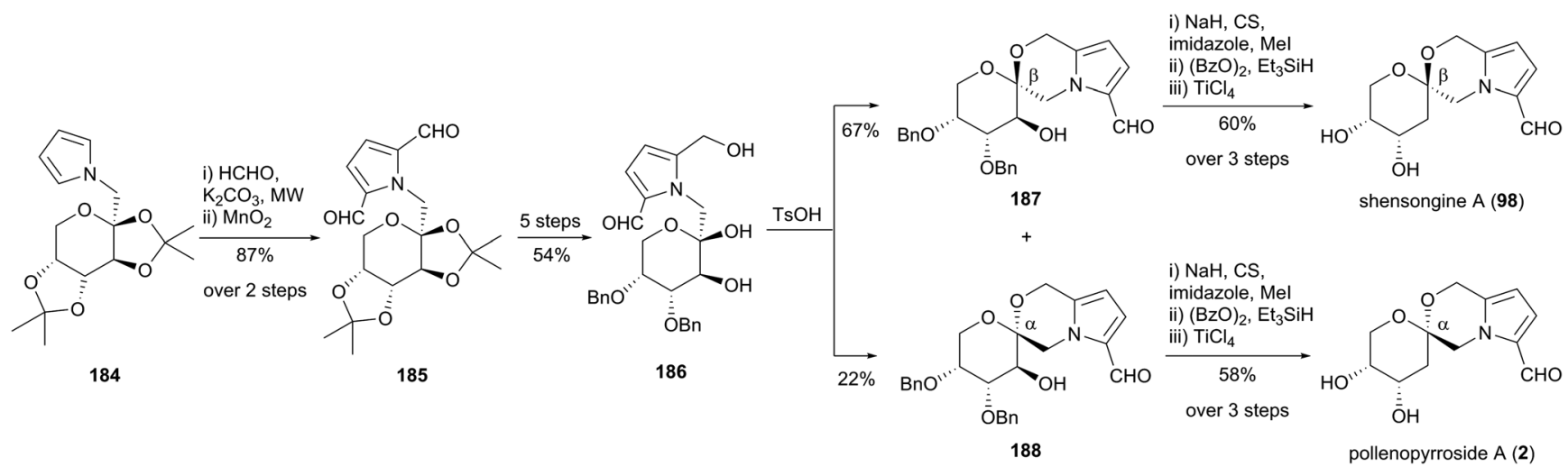

Scheme 17 Synthesis of shensongine A (98) and pollenopyrroside A (2) by Zhao and co-workers.

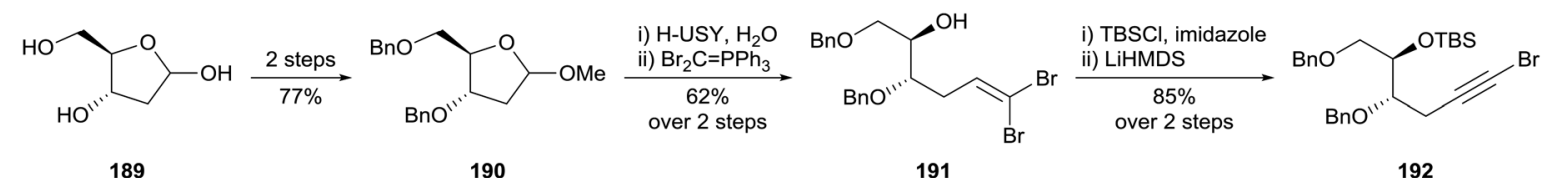<smiles>CCOCc1c[13c]c(C(=O)OCC)[nH]1</smiles>
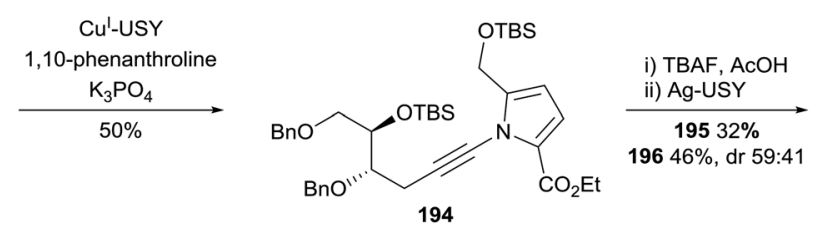<smiles>CCOC(=O)c1ccc2n1C=C(C[C@H](Cc1ccccc1)[C@H](O)COCc1ccccc1)OC2</smiles><smiles>CCOC(=O)c1ccc2n1CC1(C[C@H](O)[C@H](C[18O]c3ccccc3)O1)OC2</smiles>

195

$50 \%$ dr $54: 46$

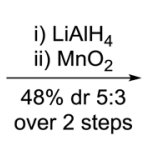

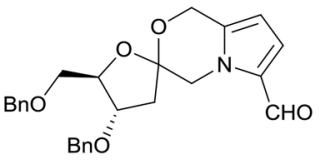

197

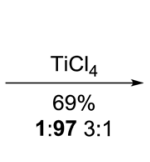

(1)

Scheme 18 Synthesis of acortatarin A (1) and shensongine B (97) by Pale and co-workers. USY = ultrastable Y-type zeolite.

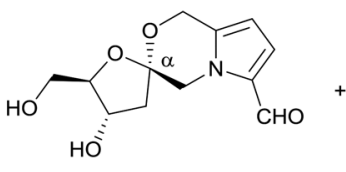

acortatarin A (1)

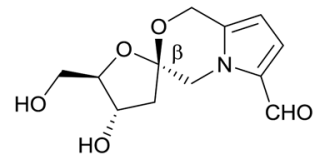

shensongine $B(97)$

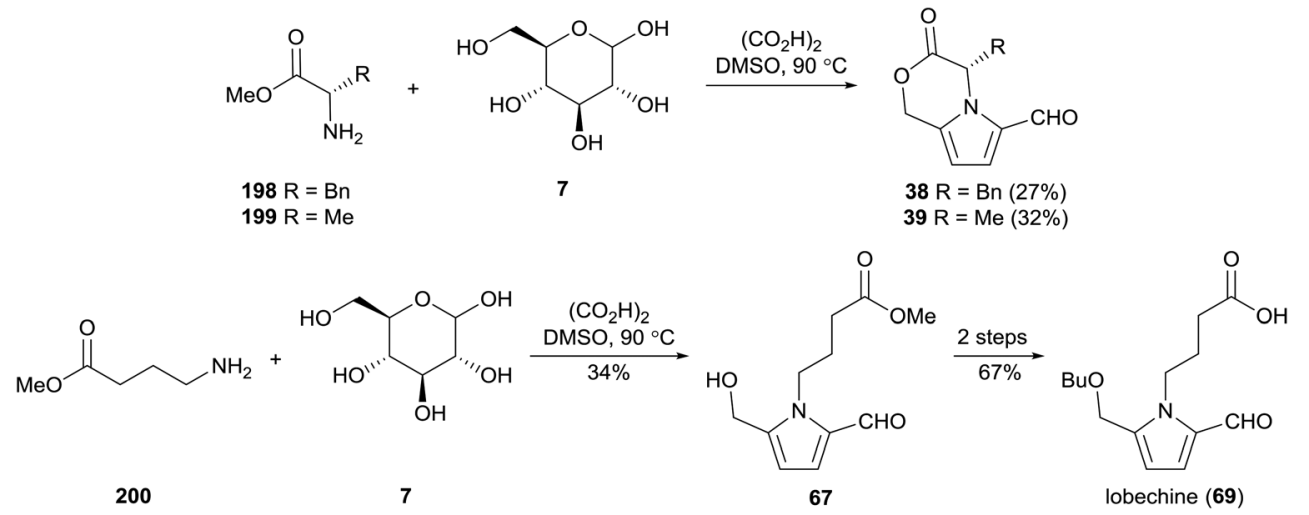

Scheme 19 Maillard-type reaction developed by Koo and co-workers. 


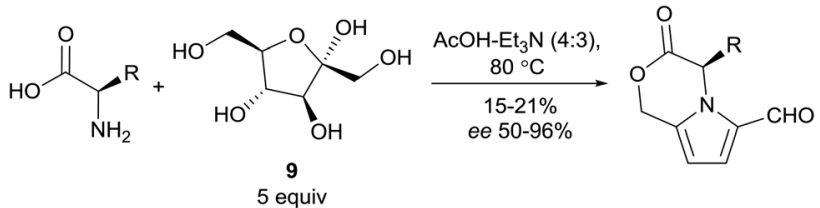

$\mathrm{R}=\mathrm{CH}_{3}, \mathrm{CH}\left(\mathrm{CH}_{3}\right)_{2}, \mathrm{CH}\left(\mathrm{CH}_{3}\right) \mathrm{CH}_{2} \mathrm{CH}_{3}, \mathrm{CH}_{2} \mathrm{CH}\left(\mathrm{CH}_{3}\right)_{2}, \mathrm{CH}_{2} \mathrm{C}_{6} \mathrm{H}_{5}$ or $\mathrm{CH}_{2} \mathrm{C}_{6} \mathrm{H}_{4} \mathrm{OH}$

Scheme 20 Maillard-type reaction developed by Zhao and coworkers.

fructose (9) (Scheme 20). ${ }^{110}$ Extensive optimisation led to the solvent mixture of acetic acid and triethylamine $(4: 3)$ and use of five equivalents of $\mathrm{D}$-fructose (9) relative to the amino acid. Chiral HPLC analysis of the products indicated that partial racemisation of the $\alpha$-stereocenter had occurred during the reaction. For substrates D-valine, D-isoleucine, D-phenylalanine and D-tyrosine, this racemisation was minimal, however substrates D-alanine and D-leucine suffered from $25 \%$ and $10 \%$ racemisation respectively.

\section{Conclusions}

Initially observed as trace products in amine-sugar reactions mixtures, 2-formylpyrroles have since been isolated from a broad range of natural sources. Derived from amines and reducing sugars by non-enzymatic Maillard pathways, these pyrroles are representative of amine metabolites present in the natural source, yet often possess unique biological activities. The most studied group of pyrrole-2-carbaldehydes - the pyrrolomorpholine spiroketals - may provide a basis for drug discovery directed towards therapeutic intervention of diabetic nephropathy and have therefore enjoyed sustained interest from the synthetic community, succumbing to eleven total syntheses from nine research groups. Inspired by the Maillard pathways responsible for 2-formylpyrroles, other research has realised the preparation of pyrroles from sugars and amines in synthetically useful yields. Such synthetic advances will aid ongoing investigations into the biological activity of 2 -formylpyrroles and may even enable the use of this compound family as highly functionalised sustainable platform chemicals.

\section{Conflicts of interest}

There are no conflicts to declare.

\section{Acknowledgements}

We thank the University of Auckland for the award of a Doctoral Scholarship (JMW).

\section{Notes and references}

1 X.-G. Tong, L.-L. Zhou, Y.-H. Wang, C. Xia, Y. Wang, M. Liang, F.-F. Hou and Y.-X. Cheng, Org. Lett., 2010, 12(8), 1844-1847.
2 J.-L. Guo, Z.-M. Feng, Y.-J. Yang, Z.-W. Zhang and P.-C. Zhang, Chem. Pharm. Bull., 2010, 58(7), 983-985.

3 B. Ding, Y. Dai, Y.-L. Hou and X.-S. Yao, J. Asian Nat. Prod. Res., 2015, 17(5), 559-566.

4 Q. Bin, D. Jiang, I. H. Cho and D. G. Peterson, Flavour Fragrance J., 2012, 27(6), 454-458.

5 D. Jiang and D. G. Peterson, Food Chem., 2013, 141(2), 13451353.

6 Y.-W. Chin, S. W. Lim, S.-H. Kim, D.-Y. Shin, Y.-G. Suh, Y.-B. Kim, Y. C. Kim and J. Kim, Bioorg. Med. Chem. Lett., 2003, 13(1), 79-81.

7 S. B. Kim, B. Y. Chang, Y. H. Jo, S. H. Lee, S.-B. Han, B. Y. Hwang, S. Y. Kim and M. K. Lee, J. Ethnopharmacol., 2013, 145(1), 393-396.

8 K. H. Kim, E. Moon, K. S. Kang, S. Y. Kim, S. U. Choi, K. R. Lee, K. H. Kim, E. Moon, K. S. Kang, S. Y. Kim, et al., J. Braz. Chem. Soc., 2015, 26(1), 3-8.

9 M.-J. Don, W.-F. Chiou, C.-C. Shen, H.-J. Yu, C.-H. Chiang, C.-C. Chen and W. Chang, Heterocycles, 2005, 65(5), 1215.

10 Z. F. Zhao, L. L. Zhou, X. Chen, Y. X. Cheng, F. F. Hou and J. Nie, Chin. Med. J., 2013, 126(7), 1230-1235.

11 H. Li and S.-J. Yu, J. Sci. Food Agric., 2018, 98, 3225-3233.

12 B. B. Butler and A. Aponick, in Strategies and Tactics in Organic Synthesis, ed. M. Harmata, Academic Press, 2015, vol. 11, pp. 1-28.

13 M. Faisal, D. Shahzad, F. A. Larik and P. Dar, Fitoterapia, 2018, DOI: 10.1016/j.fitote.2018.03.014.

14 T. M. Zenni, J. M. Cassady and R. F. Raffauf, J. Nat. Prod., 1986, 49(4), 695-698.

15 T. Matsumoto, S. Nakamura, T. Ohta, K. Fujimoto, M. Yoshikawa, K. Ogawa and H. Matsuda, Org. Lett., 2014, 16(11), 3076-3078.

16 H.-J. Yu, C.-C. Chen and B.-J. Shieh, J. Nat. Prod., 1998, 61(8), 1017-1019.

17 T. Nakayama, F. Hayase and H. Kato, Agric. Biol. Chem., 1980, 44(5), 1201-1202.

18 F. Hayase, R. H. Nagaraj, S. Miyata, F. G. Njoroge and V. M. Monnier, J. Biol. Chem., 1989, 264(7), 3758-3764.

19 M. Hellwig and T. Henle, Angew. Chem., Int. Ed., 2014, 53(39), 10316-10329.

20 J. E. Hodge, J. Agric. Food Chem., 1953, 1(15), 928-943.

21 H. Kato and M. Fujimaki, Agric. Biol. Chem., 1970, 34(7), 1071-1077.

22 G. R. Jurch and J. H. Tatum, Carbohydr. Res., 1970, 15(2), 233-239.

23 F. Ledl, in The Maillard Reaction in Food Processing, Human Nutrition and Physiology, ed. P. A. Finot, H. U. Aeschbacher, R. F. Hurrell and R. Liardon, Birkhaeuser, Basel, 1990, pp. 19-42.

24 E. F. L. Anet, Aust. J. Chem., 1960, 13(3), 396-403.

25 J. E. Hodge, in Advances in Carbohydrate Chemistry, ed. M. L. Wolfrom, Academic Press, 1955, vol. 10, pp. 169-205.

26 M. O. Lederer and M. Baumann, Bioorg. Med. Chem., 2000, 8(1), 115-121.

27 C. T. Walsh, S. Garneau-Tsodikova and A. R. Howard-Jones, Nat. Prod. Rep., 2006, 23(4), 517-531. 
28 S. Lautru, L. Song, L. Demange, T. Lombès, H. Galons, G. L. Challis and J.-L. Pernodet, Angew. Chem., Int. Ed., 2012, 51, 7454-7458.

29 A. Vingadassalon, F. Lorieux, M. Juguet, G. Le Goff, C. Gerbaud, J.-L. Pernodet and S. Lautru, ACS Chem. Biol., 2015, 10(2), 601-610.

30 J. P. Dickerson, D. L. Roberts, C. W. Miller, R. A. Lloyd and C. E. Rix, Tobacco, 1976, 178(9), 71-77.

31 R. A. Lloyd, C. W. Miller, D. L. Roberts, J. A. Giles, J. P. Dickerson, N. H. Nelson, C. E. Rix and P. H. Ayers, Tob. Sci., 1976, 20, 125-133.

32 Y. Guo, X. Li, J. Wang, J. Xu and N. Li, Fitoterapia, 2005, 76(2), 273-275.

33 S. B. Kim, B. Y. Chang, B. Y. Hwang, S. Y. Kim and M. K. Lee, Bioorg. Med. Chem. Lett., 2014, 24(24), 5656-5659.

34 J. Xiong, Y. Huang, X.-Y. Wu, X.-H. Liu, H. Fan, W. Wang, Y. Zhao, G.-X. Yang, H.-Y. Zhang and J.-F. Hu, Helv. Chim. Acta, 2016, 99(1), 83-89.

35 P. Wang, F. Kong, J. Wei, Y. Wang, W. Wang, K. Hong and W. Zhu, Mar. Drugs, 2014, 12(1), 477-490.

36 F. O. Chagas, A. M. Caraballo-Rodríguez, P. C. Dorrestein and M. T. Pupo, J. Nat. Prod., 2017, 80(5), 1302-1309.

37 E. Abe, Y. Nakatani, T. Yamanishi and S. Muraki, Proc. Jpn. Acad., Ser. B, 1978, 54(9), 542-547.

38 A. Sannai, T. Fujimori and K. Kato, Agric. Biol. Chem., 1982, 46(2), 429-433.

39 T. Yang, C. Wang, G. Chou, T. Wu, X. Cheng and Z. Wang, Food Chem., 2010, 123(3), 705-710.

40 R. C. Anderson, A. G. Kelly and J. S. Roberts, J. Agric. Food Chem., 1983, 31(2), 458-459.

41 N.-N. Yang, S.-Z. Huang, Q.-Y. Ma, H.-F. Dai, Z.-K. Guo, Z.-F. Yu and Y.-X. Zhao, Chem. Nat. Compd., 2015, 51(4), 730-732.

42 W.-Y. Liu, W.-D. Zhang, H.-S. Chen, Z.-B. Gu, T.-Z. Li and Yun-Zhou, J. Asian Nat. Prod. Res., 2003, 5(3), 159-163.

43 U. J. Youn, J. Y. Lee, Y.-S. Kil, A.-R. Han, C. H. Chae, S. Y. Ryu and E.-K. Seo, Arch. Pharmacal Res., 2016, 39(3), 321-327.

44 U. Joung Youn, Y.-S. Kil, J.-W. Nam, Y. Jin Lee, J. Kim, D. Lee, J.-H. Lee and E.-K. Seo, Helv. Chim. Acta, 2013, 96(8), 1482-1487.

45 J.-H. Choi, T. Suzuki, T. Kawaguchi, K. Yamashita, A. Morita, K. Masuda, K. Yazawa, H. Hirai and H. Kawagishi, Tetrahedron Lett., 2014, 55(26), 3596-3599.

46 J. Li, L. Pan, C. B. Naman, Y. Deng, H. Chai, W. J. Keller and A. D. Kinghorn, J. Agric. Food Chem., 2014, 62(22), 50545060.

47 S.-I. Kayano, H. Kikuzaki, T. Ikami, T. Suzuki, T. Mitani and N. Nakatani, Biosci., Biotechnol., Biochem., 2004, 68(4), 942944.

48 S.-I. Kayano, H. Kikuzaki, N. F. Yamada, A. Aoki, K. Kasamatsu, Y. Yamasaki, T. Ikami, T. Suzuki, T. Mitani and N. Nakatani, BioFactors, 2004, 21(1-4), 309-313.

49 S. B. Kim, B. Ahn, M. Kim, H.-J. Ji, S.-K. Shin, I. P. Hong, C. Y. Kim, B. Y. Hwang and M. K. Lee, J. Ethnopharmacol., 2014, 151(1), 478-484.

50 R. F. Raffauf, T. M. Zennie, K. D. Onan and P. W. Le Quesne, J. Org. Chem., 1984, 49, 2714-2718.
51 R. E. Schultes, Bot. Mus. Leafl., Harv. Univ., 1957, 17(9), 247264.

52 D. G. Lynn, K. Jaffe, M. Cornwall and W. Tramontano, J. Am. Chem. Soc., 1987, 109(19), 5858-5859.

53 T. Matsumoto, S. Nakamura, S. Nakashima, T. Ohta, M. Yano, J. Tsujihata, J. Tsukioka, K. Ogawa, M. Fukaya, M. Yoshikawa, et al., J. Nat. Med., 2016, 70(3), 376-383.

54 J. M. Wood, D. P. Furkert and M. A. Brimble, J. Nat. Prod., 2017, 80(6), 1926-1929.

55 L. Fowden, Biol. Rev., 1958, 33(4), 393-441.

56 Y. Ogawa and T. Konishi, Chem. Pharm. Bull., 2009, 57(10), 1110-1112.

57 G. P. Rizzi, Food Rev. Int., 2008, 24(4), 416-435.

58 M. Matsui, Y. Sato, H. Bando, M. Murayama, T. Osawa, T. Miura and Y. Oshima, Nat. Med., 1998, 52(3), 232-235.

59 S. Sang, A. Lao, Y. Wang, C.-K. Chin, R. T. Rosen and C.-T. Ho, J. Agric. Food Chem., 2002, 50(22), 6318-6321.

60 S. F. Farag, Y. Kimura, H. Ito, J. Takayasu, H. Tokuda and T. Hatano, J. Nat. Med., 2009, 63(1), 91.

61 Z. Zhou, J. Luo, K. Pan and L. Kong, Nat. Prod. Res., 2014, 28(14), 1065-1069.

62 X.-F. Wang, L. Yu, W.-J. Hao, L. Ma, L. Yin and X.-Y. Fu, Chem. Nat. Compd., 2016, 52(4), 769-770.

63 H. J. Jung, H. A. Jung, S. S. Kang, J.-H. Lee, Y. S. Cho, K. H. Moon and J. S. Choi, Arch. Pharmacal Res., 2012, 35(10), 1771-1777.

64 W. Chen, X.-A. Shou, Y. Chen, N. Qin, W. Qiao, S.-A. Tang and H.-Q. Duan, Chem. Nat. Compd., 2014, 50(6), 989-993.

65 P.-C. Kuo, T.-L. Hwang, Y.-T. Lin, Y.-C. Kuo and Y.-L. Leu, Arch. Pharmacal Res., 2011, 34(5), 715-722.

66 Z. Feng, Z. Zhan, Y. Yang, J. Jiang and P. Zhang, Bioorg. Chem., 2017, 74, 10-14.

67 Z. Feng, Z. Zhan, Y. Yang, J. Jiang and P. Zhang, Sci. Rep., 2016, 6, 25443.

68 L.-Y. Li, Y. Ding, I. Groth, K.-D. Menzel, G. Peschel, K. Voigt, Z.-W. Deng, I. Sattler and W.-H. Lin, J. Asian Nat. Prod. Res., 2008, 10(8), 765-770.

69 W.-G. Shan, Y. Wang, L.-F. Ma and Z.-J. Zhan, J. Chem. Res., 2014, 38, 245-246.

70 Y.-P. Yang, M.-J. Cheng, C.-M. Teng, Y.-L. Chang, I.-L. Tsai and I.-S. Chen, Phytochemistry, 2002, 61(5), 567-572.

71 J.-H. Choi, N. Ozawa, Y. Yamakawa, K. Nagai, H. Hirai and H. Kawagishi, Tetrahedron, 2011, 67(35), 6649-6653.

72 G. A. Zou, S. Mansur, S. C. Hu, H. A. Aisa and K. M. Shakhidoyatov, Chem. Nat. Compd., 2012, 48(4), 635-637.

73 L. Han, C. Gao, Y. Jiang, P. Guan, J. Liu, L. Li, L. Xu and X. Huang, J. Nat. Prod., 2014, 77(12), 2605-2610.

74 J.-J. Xia, Y.-D. Li, X.-M. Liu, Y. Lu, Y.-Q. Wu and Y.-H. Qin, J. Asian Nat. Prod. Res., 2016, 18(8), 779-783.

75 G.-H. Xu, Y.-H. Kim, S.-J. Choo, I.-J. Ryoo, J.-K. Yoo, J.-S. Ahn and I.-D. Yoo, Arch. Pharmacal Res., 2009, 32(9), 1215-1220.

76 Q. Li, A.-J. Deng, L. Li, L.-Q. Wu, M. Ji, H.-J. Zhang, Z.-H. Li, L. Ma, Z.-H. Zhang, X.-G. Chen, et al., J. Nat. Prod., 2017, 80(8), 2189-2198.

77 X.-F. Yang, X.-H. Cao, Y.-M. Ma and K. Qiao, Nat. Prod. Res., 2018, 32(3), 302-307. 
78 J. Yu, X. Wang, H. Yan, Y. Geng, X. Wang and H. Zhao, Chn. Pat., 107698510A, February 16, 2018.

79 T. Kikuchi, A. Ikedaya, A. Toda, K. Ikushima, T. Yamakawa, R. Okada, T. Yamada and R. Tanaka, Phytochem. Lett., 2015, 12, 94-97.

80 M.-D. Wu, M.-J. Cheng, I.-S. Chen, Y.-S. Su, S.-Y. Hsieh, H.-S. Chang, C.-W. Chang and G.-F. Yuan, Chem. Biodiversity, 2013, 10(3), 493-505.

81 A. Hiermann, S. Kedwani, H. W. Schramm and C. Seger, Fitoterapia, 2002, 73(1), 22-27.

82 L. Xiong, C. Peng, X.-F. Xie, L. Guo, C.-J. He, Z. Geng, F. Wan, O. Dai and Q.-M. Zhou, Molecules, 2012, 17(8), 9939-9946.

83 H. Li, J. Xiao, Y.-Q. Gao, J. Tang, A.-L. Zhang and J.-M. Gao, J. Agric. Food Chem., 2014, 62(17), 3734-3741.

84 M.-J. Don, C.-C. Shen, Y.-L. Lin, W.-J. Syu, Y.-H. Ding and C.-M. Sun, J. Nat. Prod., 2005, 68(7), 1066-1070.

85 L.-L. Liu, J.-L. Yang and Y.-P. Shi, J. Asian Nat. Prod. Res., 2011, 13(10), 920-929.

86 N. W. Fan, H. S. Chang, M. J. Cheng, H. Y. Chan, S. Y. Hsieh, T. W. Liu, S. W. Chen, G. F. Yuan and I. S. Chen, Chem. Nat. Compd., 2016, 52(4), 585-590.

87 M.-J. Cheng, H.-Y. Chan, Y.-C. Cheng, M.-D. Wu, J.-J. Chen, Y.-L. Chen, S.-Y. Hsieh, G.-F. Yuan and Y.-S. Su, Chem. Nat. Compd., 2015, 51(3), 515-518.

88 H. Zhou, R. Zhao and J. Yang, Nat. Prod. Res., 2013, 27(8), 687-690.

89 M. Li, J. Xiong, Y. Huang, L.-J. Wang, Y. Tang, G.-X. Yang, X.-H. Liu, B.-G. Wei, H. Fan, Y. Zhao, W.-Z. Zhai and J.-F. Hu, Tetrahedron, 2015, 71(33), 5285-5295.

90 S. Giunti, D. Barit and M. E. Cooper, Minerva Med., 2006, 97(3), 241-262.

91 A. L. Verano and D. S. Tan, Chem. Sci., 2017, 8(5), 36873693.

92 P. Hayoz, A. Aeby and R. Neier, Chimia, 1993, 47, 230-232.

93 Y. Dong, N. N. Pai, S. L. Ablaza, S.-X. Yu, S. Bolvig, D. A. Forsyth and P. W. Le Quesne, J. Org. Chem., 1999, 64(8), 2657-2666.
94 S. L. Ablaza, N. N. Pai and P. W. L. Quesne, Nat. Prod. Lett., 1995, 6(1), 77-80.

95 S.-X. Yu and P. W. Le Quesne, Tetrahedron Lett., 1995, 36(35), 6205-6208.

96 O. Tamura, N. Iyama and H. Ishibashi, J. Org. Chem., 2004, 69(5), 1475-1480.

97 T. Okada, K. Sakaguchi, T. Shinada and Y. Ohfune, Tetrahedron Lett., 2011, 52(44), 5744-5746.

98 T.-Y. Yuen, S. E. Eaton, T. M. Woods, D. P. Furkert, K. W. Choi and M. A. Brimble, Eur. J. Org. Chem., 2014, 2014(7), 1431-1437.

99 H. M. Geng, J. L.-Y. Chen, D. P. Furkert, S. Jiang and M. A. Brimble, Synlett, 2012, 23(06), 855-858.

100 G. Sudhakar, V. D. Kadam, S. Bayya, G. Pranitha and B. Jagadeesh, Org. Lett., 2011, 13(20), 5452-5455.

101 T. Teranishi, M. Kageyama and S. Kuwahara, Biosci., Biotechnol., Biochem., 2013, 77(3), 676-678.

102 H. M. Geng, L. A. Stubbing, J. Li-yang Chen, D. P. Furkert and M. A. Brimble, Eur. J. Org. Chem., 2014, 2014(28), 6227-6241.

103 J. M. Wood, D. P. Furkert and M. A. Brimble, Org. Biomol. Chem., 2016, 14(32), 7659-7664.

104 J. M. Wurst, A. L. Verano and D. S. Tan, Org. Lett., 2012, 14(17), 4442-4445.

105 N. V. Borrero and A. Aponick, J. Org. Chem., 2012, 77(19), 8410-8416.

106 Z. Cao, Y. Li, S. Wang, X. Guo, L. Wang and W. Zhao, Synlett, 2015, 26(07), 921-926.

107 S. Huo, Y. Li, C. Liang, J. Liu and W. Zhao, J. Carbohydr. Chem., 2011, 30(2), 75-84.

108 E. Wimmer, S. Borghèse, A. Blanc, V. Bénéteau and P. Pale, Chem.-Eur. J., 2017, 23(7), 1484-1489.

109 N. D. Adhikary, S. Kwon, W.-J. Chung and S. Koo, J. Org. Chem., 2015, 80(15), 7693-7701.

110 Z. Cao, Y. Li, S. Wang, B. Tang, X. Guo, L. Wang and W. Zhao, Tetrahedron Lett., 2016, 57(21), 2219-2221. 